\title{
CESM/CAM5 improvement and application: comparison and evaluation of updated CB05_GE and MOZART-4 gas-phase mechanisms and associated impacts on global air quality and climate
}

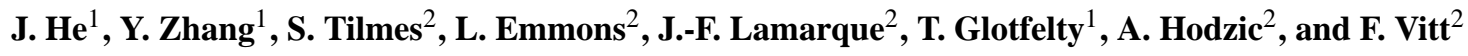 \\ ${ }^{1}$ Department of Marine, Earth, and Atmospheric Sciences, North Carolina State University, Raleigh, NC, USA \\ ${ }^{2}$ National Center for Atmospheric Research, Boulder, CO, USA \\ Correspondence to: Y. Zhang (yang_zhang@ncsu.edu)
}

Received: 13 July 2015 - Published in Geosci. Model Dev. Discuss.: 27 August 2015

Revised: 18 November 2015 - Accepted: 24 November 2015 - Published: 16 December 2015

\begin{abstract}
Atmospheric chemistry plays a key role in determining the amounts and distributions of oxidants and gaseous precursors that control the formation of secondary gaseous and aerosol pollutants; all of those species can interact with the climate system. To understand the impacts of different gas-phase mechanisms on global air quality and climate predictions, in this work, a comprehensive comparative evaluation is performed using the Community Atmosphere Model (CAM) Version 5 with comprehensive tropospheric and stratospheric chemistry (CAM5-chem) within the Community Earth System Model (CESM) with the two most commonly used gas-phase chemical mechanisms: the 2005 Carbon Bond mechanism with Global Extension (CB05_GE) and the Model of OZone and Related chemical Tracers version 4 (MOZART-4) mechanism with additional updates (MOZART-4x). MOZART-4x and CB05_GE use different approaches to represent volatile organic compounds (VOCs) and different surrogates for secondary organic aerosol (SOA) precursors. MOZART-4x includes a more detailed representation of isoprene chemistry compared to CB05_GE. CB05_GE includes additional oxidation of $\mathrm{SO}_{2}$ by $\mathrm{O}_{3}$ over the surface of dust particles, which is not included in MOZART-4x. The results show that the two CAM5-chem simulations with CB05_GE and MOZART-4x predict similar chemical profiles for major gases (e.g., $\mathrm{O}_{3}$, $\mathrm{CO}$, and $\mathrm{NO}_{x}$ ) compared to the aircraft measurements, with generally better agreement for $\mathrm{NO}_{y}$ profiles by $\mathrm{CB} 05 \_\mathrm{GE}$ than MOZART-4x. The concentrations of SOA at four sites in the continental US (CONUS) and organic carbon (OC)
\end{abstract}

over the IMPROVE sites are well predicted by MOZART-4x (with normalized mean biases (NMBs) of -1.9 and $2.1 \%$, respectively) but moderately underpredicted by CB05_GE (with NMBs of -23.1 and $-20.7 \%$, respectively). This is mainly due to the higher biogenic emissions and $\mathrm{OH}$ levels simulated with MOZART-4x than with CB05_GE. The concentrations of OC over Europe are largely underpredicted by both MOZART-4x and CB05_GE, with NMBs of -73.0 and $-75.1 \%$, respectively, indicating the uncertainties in the emissions of precursors and primary OC and relevant model treatments such as the oxidations of VOCs and SOA formation. Uncertainties in the emissions and convection scheme can contribute to the large bias in the model predictions (e.g., $\mathrm{SO}_{2}, \mathrm{CO}$, black carbon, and aerosol optical depth). The two simulations also have similar cloud/radiative predictions, with a slightly better performance of domain average cloud condensation nuclei $(\mathrm{CCN})$ at supersaturation of $0.5 \%$ by CB05_GE, but slightly better agreement with observed CCN (at supersaturation of $0.2 \%$ ) profile over Beijing by MOZART-4x. The two gas-phase mechanisms result in a global average difference of $0.5 \mathrm{~W} \mathrm{~m}^{-2}$ in simulated shortwave cloud radiative forcing, with significant differences (e.g., up to $13.6 \mathrm{~W} \mathrm{~m}^{-2}$ ) over subtropical regions. 


\section{Introduction}

Atmospheric chemistry plays an important role in the perturbation of the climate system by determining the amounts and distributions of important oxidants and gaseous precursors for secondary air pollutants such as ozone $\left(\mathrm{O}_{3}\right)$ and aerosols (IPCC, 2013). Aerosols can influence the Earth's radiative balance by directly scattering and absorbing radiation and indirectly affecting cloud properties by acting as cloud condensation nuclei (CCN) and ice nuclei (IPCC, 2013). The aerosol effects on radiation depend critically on their chemical composition and physical properties. Therefore, atmospheric chemistry is an important component of atmospheric and Earth system models. Different chemical mechanisms (e.g., different chemical reactions and kinetic parameters) can lead to differences in the predictions of gases, secondary aerosols, as well as climatic variables such as $\mathrm{CCN}$, cloud droplet number concentration (CDNC), and radiative forcings (Luecken et al., 2008; Sarwar et al., 2008; Zhang et al., 2012a; Lamarque et al., 2013).

There are generally two types of species in the gas-phase mechanisms: inorganic and organic. Although most mechanisms include the same important inorganic species (e.g., $\mathrm{O}_{3}$, carbon monoxide $(\mathrm{CO}), \mathrm{HO}_{x}$ (odd hydrogen = hydroxyl radical, $\mathrm{OH}+$ hydroperoxyl radical, $\mathrm{HO}_{2}$ ) and nitrogen oxides $\left.\left(\mathrm{NO}_{x}\right)\right)$, the predicted amounts can vary greatly among different mechanisms (Knote et al., 2014a). Some mechanisms ignore reactions with very low reaction rates since they do not affect results significantly. Also, some reactions may use different rate coefficients with different dependence on atmospheric temperature and pressure due to the uncertainties in the laboratory measurements or the use of mechanisms that have not been updated in time. Unlike inorganic species, there are more significant differences in the representation of organic species. Light organic species with low molecular weight are often explicitly treated (e.g., methane, formaldehyde, $\mathrm{HCHO}$ ), whereas lumped or surrogate species are used to represent more complex mixtures of heavy organic compounds with high molecular weight (e.g., aromatics, organic nitrates). There are the three most common representations of organic chemistry, including the lumped structure technique, the surrogate species approach, and the lumped species method (Zhang et al., 2004). For example, the Carbon Bond mechanism version IV (CB-IV, Gery et al., 1989), which uses the lumped structure approach for volatile organic compounds (VOCs), has been widely used in air quality modeling systems through urban to regional scales for many years. This mechanism was later extensively updated in 2005 (CB05, Yarwood et al., 2005), and has been implemented in the Community Multiscale Air Quality model (CMAQ, Sarwar et al., 2008) and the Weather Research and Forecasting model with Chemistry (WRF-Chem, Wang et al., 2014). CB05 has been further expanded to include more than 120 reactions that are important on a global scale (CB05 with global extension, CB05_GE; Karamchan- dani et al., 2012) and implemented in global models, such as the Global-through-Urban WRF/Chem (GU-WRF/Chem, Zhang et al., 2012a) and the Community Atmosphere Model version 5 (CAM5), the atmospheric component of the Community Earth System Model (CESM/CAM5, He and Zhang, 2014). The Model of OZone and Related chemical Tracers version 4 (MOZART-4, Emmons et al., 2010) mechanism, which uses the lumped species approach for VOCs, has also been used in WRF-Chem (Knote et al., 2014b) and CAM with extensive tropospheric and stratospheric chemistry (CAM-chem) versions 4 and 5 (Lamarque et al., 2012; Tilmes et al., 2015). Different gas-phase mechanisms have also been compared in several studies, however, most of which are conducted in box models or using regional models (Kim et al., 2009, 2011a, b; Yu et al., 2010). For example, using WRF-Chem, Zhang et al. (2012b) found that three different mechanisms (i.e., the Carbon Bond Mechanism-Z, CBM-Z, the 1999 Statewide Air Pollution Research Center Mechanism, SAPRC99, and the CB05) can predict different $\mathrm{O}_{3}$ concentrations up to $5 \mathrm{ppb}$ at the surface in July 2001 . $\mathrm{Yu}$ et al. (2010) compared the $\mathrm{O}_{3}$ predictions from three different mechanisms (i.e., CB4, CB05, and SAPRC99) using Eta-CMAQ and found that at the AIRNow surface sites, CB05 gives the best $\mathrm{O}_{3}$ performance, followed by $\mathrm{CB} 4$ and SAPRC-99 for observed $\mathrm{O}_{3} \geq 75 \mathrm{ppb}$, whereas CB4 gives the best $\mathrm{O}_{3}$ performance for observed $\mathrm{O}_{3}<75 \mathrm{ppb}$. Knote et al. (2014a) also compared seven chemical mechanisms using a box model and found that the differences in daytime $\mathrm{OH}$ radical concentrations can be up to $40 \%$.

Climate change can also strongly influence atmospheric chemistry and aerosols and therefore air quality. For example, photolysis and temperature-dependent reactions can be directly impacted by climate change (Jacob and Winner, 2009). Due to the nonlinear relationships between chemistry, aerosols, and climate, it is important to accurately represent their interactions in a three-dimensional global model. Several studies have demonstrated the capability of CAM-chem to represent tropospheric (Aghedo et al., 2011; Lamarque et al., 2010, 2011a, b; Tilmes et al., 2015) and stratospheric (Lamarque et al., 2008; Lamarque and Solomon, 2010) conditions. The chemical mechanism used in CAM-chem is based on MOZART-4, with detailed stratospheric chemistry of Kinnison et al. (2007). In this work, the two most commonly used gas-phase mechanisms, the extended MOZART4 (with updates as described by Knote et al. (2014b) and additional updates in this work) (referred to as MOZART-4x) and the CB05_GE chemical mechanisms, are compared using the latest CESM/CAM5. The objectives are to examine the differences in the secondary organic aerosol (SOA) predictions resulting from the two gas-phase chemical mechanisms and to study the sensitivity of air quality and climate predictions to different gas-phase chemical mechanisms. 


\section{Model descriptions}

The CESM/CAM5 used in this work is based on CAM version 5.3 of CESM version 1.2.2, coupled to comprehensive tropospheric and stratospheric chemistry (CAM5-chem, Tilmes et al., 2015) using the seven-mode Modal Aerosol Model (MAM7) (Liu et al., 2012). This version of CAM5chem was further developed and improved at North Carolina State University (NCSU) in collaboration with NCAR, as described below. A more detailed description of this version of CESM CAM5-chem (referred to as CAM5-NCSU hereafter) used in this study can be found in He and Zhang (2014) and He et al. (2015).

\subsection{Chemical mechanisms}

In this study, CB05_GE has been updated to include additional kinetic reactions describing interactions between functionalization and fragmentation processes during gas-phase oxidation of anthropogenic and biogenic VOCs by OH (Glotfelty et al., 2015). The products of those reactions are linked with the organic gas/particle partitioning for SOA formation. Heterogeneous reactions on tropospheric aerosols and stratospheric clouds are also added, same as those in MOZART4x (Tilmes et al., 2015), with one additional pathway in CB05_GE to simulate sulfate formation through oxidation of sulfur dioxide $\left(\mathrm{SO}_{2}\right)$ by $\mathrm{O}_{3}$ on the surface of dust particles.

MOZART-4x used in this work extends the MOZART chemical mechanism used in Lamarque et al. (2012) and Tilmes et al. (2015) to include several updates as described in Knote et al. (2014b). These updates include (1) detailed treatments of monoterpenes ( $\alpha$-pinene, $\beta$-pinene, and limonene) and 2-methyl-3-buten-2-ol (MBO); (2) detailed treatments of aromatics (e.g., benzene, toluene, and xylenes); (3) additional glyoxal $\left(\mathrm{C}_{2} \mathrm{H}_{2} \mathrm{O}_{2}\right)$ production from oxidized VOC products; and (4) an updated isoprene (ISOP) oxidation scheme. In this work, the oxidation of anthropogenic and biogenic VOCs and subsequent aging processes are also included in MOZART-4x, and the products of those reactions are linked with the organic gas/particle partitioning for SOA formation.

Table 1 shows the gas-phase organic precursors for SOA formation treated in MOZART-4x and CB05_GE. For aromatic precursors of SOA, MOZART-4x includes benzene, toluene (TOL), xylenes, and cresol. Although CB05_GE does not include benzene, it includes polycyclic aromatic hydrocarbons (PAH) as a SOA precursor. For alkane precursors of SOA, MOZART-4x includes BIGALK (lumped alkanes with carbon, C, number $>3$ ), whereas CB05_GE includes ALKH (long-chain alkanes, with $\mathrm{C}>6$ ). For anthropogenic alkene precursors of SOA, MOZART-4x includes propene $\left(\mathrm{C}_{3} \mathrm{H}_{6}\right)$ and BIGENE (lumped alkenes with $\mathrm{C}>3$ ), whereas CB05_GE includes terminal olefin (OLE) and internal olefin (IOLE). The emissions for biogenic alkene precursors are from the Model of Emissions of Gases and
Aerosols from Nature version 2.1 (MEGAN2.1, Guenther et al., 2012). Both MOZART-4x and CB05_GE include $\alpha$-pinene (APIN), $\beta$-pinene (BPIN), limonene, and ISOP as precursors for biogenic SOA. CB05_GE also includes additional biogenic precursors such as speciated ocimene (OCI), humulene (HUM) and terpinene (TER). However, in MOZART-4x, the species mapping for MEGAN emission calculation is slightly different. For example, $\alpha$-pinene and other compounds (e.g., $\alpha$-thujene, p-cymene, and o-cymene) are mapped into APIN, $\beta$-pinene and other compounds (e.g., sabinene and camphene) are mapped into BPIN, limonene and other compounds (e.g., phellandrene and terpinene) are mapped into LIMON, myrcene and other compounds (e.g., ocimene) are mapped into MYRC, and $\beta$-caryophyllene and other sesquiterpenes (e.g., humulene and $\alpha$-bergamotene) are mapped into BCARY. Due to the different mapping for MEGAN species, biogenic emissions between MOZART-4x and CB05_GE are different, which can result in different biogenic SOA predictions. On the other hand, the rate coefficients for the oxidations of biogenic VOCs (e.g., APIN, BPIN, and limonene) are constant in CB05_GE, whereas they are temperature-dependent in MOZART- $4 x$; such a difference can result in different SOA predictions as well. In addition, there are uncertainties in the $\mathrm{HO}_{x}$ recycling associated with isoprene chemistry in CB05_GE (Karamchandani et al., 2012), whereas MOZART-4x used in this work includes OH recycling from improved isoprene chemistry. For example, in CB05_GE, ISOP is oxidized by $\mathrm{OH}$ to generate a $91.2 \%$ molar yield of $\mathrm{HO}_{2}$. In MOZART-4x, the isoprene peroxy radical from the oxidation ISOP by OH (i.e., ISOPO2) has different yields of $\mathrm{HO}_{2}$ through reactions with nitrogen monoxide (NO), nitrate radical $\left(\mathrm{NO}_{3}\right)$, methylperoxy radical $\left(\mathrm{CH}_{3} \mathrm{O}_{2}\right)$, and acetylperoxy radical $\left(\mathrm{CH}_{3} \mathrm{CO}_{3}\right)$, and it can also consume $\mathrm{HO}_{2}$ itself. These reactions have different reaction rate coefficients. These differences can affect $\mathrm{O}_{3}, \mathrm{OH}$, and $\mathrm{NO}_{x}$ predictions, and thus the oxidation of VOCs.

\subsection{Aerosol/cloud treatments}

In CAM5-NCSU, the aerosol module is based on MAM7 of Liu et al. (2012), with improvements in terms of condensation, nucleation, aerosol thermodynamics, and aerosol activation (He and Zhang, 2014; Gantt et al., 2014). The major updates include (1) the new particle formation treatments with a combination of the default nucleation parameterizations of Vehkamaki et al. (2002) and Merikanto et al. (2007), and a newly added ion-mediated aerosol nucleation (Yu, 2010) above the planetary boundary layer (PBL), and a combination of the three and an additional parameterization of Wang and Penner (2009) in the PBL; (2) the inorganic aerosol thermodynamics based on ISORROPIA II of Fountoukis and Nenes (2007), which explicitly simulates the thermodynamics of sulfate $\left(\mathrm{SO}_{4}^{2-}\right)$, ammonium $\left(\mathrm{NH}_{4}^{+}\right)$, nitrate $\left(\mathrm{NO}_{3}^{-}\right)$, sodium $\left(\mathrm{Na}^{+}\right)$, and chloride $\left(\mathrm{Cl}^{-}\right)$in the Aitken, accumulation, and fine sea-salt modes, as well as the im- 
Table 1. Gas-phase organic aerosol precursors in the two mechanisms.

\begin{tabular}{lll}
\hline Precursors & MOZART-4x $^{\mathrm{a}}$ & CB05_GE \\
\hline Aromatics & $\begin{array}{l}\text { TOLUENE, BENZENE, } \\
\text { XYLENES, CRESOL }\end{array}$ & TOL, XYL, CRES, PAH \\
\hline Alkanes & BIGALK & ALKH \\
\hline Anthropogenic alkenes & C3H6, BIGENE & OLE, IOLE \\
\hline Biogenic alkenes & APIN, BPIN, LIMON, & $\begin{array}{l}\text { APIN, BPIN, LIM, OCI, } \\
\text { MYRC, BCARY, ISOP }\end{array}$ \\
\hline
\end{tabular}

${ }^{a}$ BIGALK: lumped alkanes $\mathrm{C}>3 ; \mathrm{C}_{3} \mathrm{H}_{6}$ : propene; BIGENE: lumped alkenes $\mathrm{C}>3$; APIN:

$\alpha$-pinene + others; BPIN: $\beta$-pinene + others; LIMON: limonene + others; MYRC: myrcene + others;

BCARY: beta-caryophyllene + other sesquiterpenes; ISOP: isoprene. ${ }^{b}$ TOL: toluene and other monoalkyl

aromatics; XYL: xylene and other polyalkyl aromatics; CRES: cresol and higher molecular weight phenols;

PAH: polycyclic aromatic hydrocarbons; ALKH: long-chain alkanes, C > 6; OLE: terminal olefin carbon

bond $(\mathrm{R}-\mathrm{C}=\mathrm{C})$; IOLE: internal olefin carbon bond $(\mathrm{R}-\mathrm{C}=\mathrm{C}-\mathrm{R})$; APIN: $\alpha$-pinene; BPIN: $\beta$-pinene; LIM

limonene; OCI: ocimene; HUM: humulene; TER: terpinene; ISOP: isoprene.

pact of crustal species associated with the fine dust mode; (3) an advanced aerosol activation scheme based on Fountoukis and Nenes (2005) with additional updates based on Kumar et al. (2009) and Barahona et al. (2010), which accounts for adsorption activation from insoluble $\mathrm{CCN}$ and a giant $\mathrm{CCN}$ equilibrium timescale on aerosol activation.

CAM5-NCSU also includes an advanced treatment for SOA formation based on a volatility-basis-set (VBS) approach that has been coupled with CB05_GE by Glotfelty et al. (2015) and is also coupled with MOZART-4x in this work. This approach consists of two primary components: (1) volatile SOA (VSOA) formation from anthropogenic VOCs (AVOCs) and biogenic VOCs (BVOCs) and (2) the volatility and aging of primary organic aerosol (POA) and the repartitioning of the semi/intermediate volatility compounds (S/IVOC) into SOA. The VSOA treatment is based on the treatment of Tsimpidi et al. (2010). The products of VOC oxidation are mapped onto the volatility distribution using the aerosol mass yields listed in Tsimpidi et al. (2010) using the CB05_GE species that represent those precursor VOCs. An additional pathway for the formation of SOA from PAH is also added in CB05_GE. The SOA mass yields for PAHs are derived from the laboratory measurements of Chan et al. (2009) following the approach of Stainer et al. (2008), where the SOA mass yields for naphthalene, 1-methylnaphthalene, and 2-methylnaphthalene are averaged as surrogates for PAHs. The volatility of POA and the subsequent formation of SOA from POA vapors are based on the work of Robinson et al. (2007) and Shrivastava et al. (2008). POA emissions are distributed into nine logarithmically spaced volatility bins with effective saturation $\left(C^{*}\right)$ values ranging from $10^{-2}$ to $10^{6} \mu \mathrm{g} \mathrm{m}^{-3}$. An updated emission spectrum is used to distribute the POA emissions into the volatility bins as the emission spectrum used in Robinson et al. (2007) has been shown to be too volatile (Cappa and Jimenez, 2010; Hodzic et al., 2010; Jathar et al., 2011). This new emission spectrum maps the anthropogenic POA emissions onto the volatility distribution based on thermodenuder measurements of gasoline exhaust and also contains separate emissions fractions for biomass burning aerosol that is less volatile than anthropogenic POA (May et al., 2013a, b). The emission spectrum of Robinson et al. (2007) also assumes that the emissions of SVOCs are fully captured by the original POA emissions and missing IVOCs are assumed to be equivalent to 1.5 times the POA emissions inventory with these additional emissions placed in the three highest volatility bins. However, because the estimations of the missing IVOC emissions are poorly constrained, the 1.5 times the POA mass for IVOCs is not included in this study.

In addition to the classic one-dimensional VBS treatment as described above, functionalization and fragmentation treatment described in Shrivastava et al. (2013) are included in this version of VBS for both VSOA and S/IVOCs (referred to as $1.5 \mathrm{D}$ VBS). In this treatment, the VSOA and S/IVOCs in each volatility bin are split into three different species representing three generations of oxidation. During the first two generations of oxidation the mass of the VSOA and S/IVOCs grows by $15 \%$, reflecting the addition of oxygen atoms. In this aging scheme, not only do the masses of VSOA and S/IVOCs increase in generation when oxidized by $\mathrm{OH}$ (at a rate of $1.0 \times 10^{-11}$ and $4.0 \times$ $10^{-11} \mathrm{~cm}^{3}$ molecule ${ }^{-1} \mathrm{~s}^{-1}$, respectively), but their volatility also decreases as they are moved into smaller volatility bins. Fragmentation occurs once the VSOA and S/IVOCs have aged to the third generation. This represents the breaking of carbon bonds, which can increase volatility of the organic species, thus reducing SOA formation. This is parameterized by allowing $17.25 \%$ of the organic mass to pass to the next lowest volatility bin but passing $75 \%$ of the VSOA and S/IVOC to the highest volatility bin in the VBS structure. The remaining mass is assumed to be lost to species of higher volatility than the VBS structure. There are several differences between the VBS used in this work and Shrivastava et al. (2015). For example, nine volatility bins are used in 
this work to represent the aging and gas-particle partitioning of POA, instead of the five volatility bins used in Shrivastava et al. (2015). In addition, compared to Reaction (3) in Shrivastava et al. (2015), we do not have the third term, which denotes additional fragmentation where $10 \%$ of the mass results in low carbon number species with very high volatility that is eventually oxidized to carbon monoxide $(\mathrm{CO}) /$ carbon dioxide $\left(\mathrm{CO}_{2}\right)$ and/or removed by dry deposition. In the model treatment used in this work, the remaining mass is assumed to be lost to species with a volatility higher than the volatility values in the VBS structure. A more detailed description of SOA formation from the VBS approach is summarized in Glotfelty et al. (2015).

\section{Model configurations and evaluation protocols}

\subsection{Model setup and inputs}

The simulations are performed with a specified dynamics configuration, of which winds and temperature are driven by the Goddard Earth Observing System Model, Version 5 (GEOS-5) meteorology. The internally derived meteorological fields are nudged every time step $(30 \mathrm{~min})$ by $10 \%$ towards analysis fields from GEOS-5. The nudged meteorological fields include surface pressure, meridional wind, zonal wind, zonal surface stress, meridional surface stress, snow height, solar flux at surface, soil moisture fraction, surface temperature, temperature, specific humidity, surface geopotential, orography flag, surface water flux, and surface sensible flux. The simulations are conducted for a 3 -year period of 2008-2010 at a horizontal resolution of $0.9^{\circ} \times 1.25^{\circ}$ and a vertical resolution of 56 layers for CAM5. The initial chemical conditions are generated with the same configurations with 1-year spinup.

The offline emissions used in this work are based on those used in Tilmes et al. (2015), of which the anthropogenic and biofuel emissions are from the Monitoring Atmospheric Composition and Climate/CityZen (MACCity) emission data set (Granier et al., 2011), and biomass burning emissions are taken from the Atmospheric Chemistry and Climate Model Intercomparison Project (ACCMIP) historical emissions data set (Lamarque et al., 2010). The ACCMIP emissions are extrapolated for 2008-2010 with the Representative Concentration Pathway (RCP) 8.5 scenario and extended for VOCs and several other species for MOZART-4x species. MOZART-4x species are then mapped into CB05_GE species to generate emissions for CB05_GE species. Although both MOZART4x and CB05_GE simulate bromine chemistry, no bromine emissions are included. For bromine/chlorine species (e.g., CF2CLBR, CF3BR, CFC11, CFC12, CH3BR, and CH3CL), their surface concentrations are specified using the historical reconstruction from Meinshausen et al. (2011).

The online emissions include biogenic VOCs from MEGAN2.1 (Guenther et al., 2012), lightning $\mathrm{NO}_{x}$ (Price and Rind, 1992; Price et al., 1997), mineral dust (Zender et al., 2003), and sea salt (Martensson et al., 2003).

\subsection{Available measurements for model evaluation}

A number of observational data sets from surface networks and satellites are used for model evaluation. They are summarized along with the variables to be evaluated in Table 2. The global surface network includes data sets from the National Oceanic and Atmospheric Administration Climate Diagnostics Center (NOAA/CDC). The satellite data sets include the Moderate Resolution Imaging Spectroradiometer (MODIS) for the retrievals of cloud properties, the Clouds and Earth's Radiant Energy System (CERES) Energy Balanced and Filled (EBAF) data product for the retrievals of radiation fluxes at surface and top of atmosphere, the Aura Ozone Monitoring Instrument in combination with the Aura Microwave Limb Sounder (OMI/MLS) for the tropospheric ozone retrieval, the Measurements Of Pollution In The Troposphere (MOPITT) for tropospheric CO retrieval, and the SCanning Imaging Absorption spectroMeter for Atmospheric CHartographY (SCIAMACHY) for the retrievals of tropospheric nitrogen dioxide $\left(\mathrm{NO}_{2}\right)$, HCHO, and $\mathrm{C}_{2} \mathrm{H}_{2} \mathrm{O}_{2}$. Other satellite-based data include the MODISderived CDNC and cloud liquid water path (LWP) by Bennartz (2007).

Regional observational networks include the Clean Air Status and Trends Network (CASTNET), the Interagency Monitoring of Protected Visual Environments (IMPROVE), the Speciation Trends Network (STN), and the Air Quality System (AQS) over CONUS; the European Monitoring and Evaluation Program (EMEP), the Base de Données sur la Qualité de l'Air (BDQA, France), and the European air quality database (AirBase) over Europe; the Ministry of Environmental Protection of China (MEPC), the National Institute for Environmental Studies of Japan (NIESJ), the Korean Ministry Of Environment (KMOE), and the Taiwan Air Quality Monitoring Network (TAQMN) over East Asia. In addition to the data from the above networks, SOA measurements collected by Lewandowski et al. (2013) at four field study sites including Cleveland and Medina, OH (JulyAugust 2009), and Bakersfield and Pasadena, CA (MayJune 2010), are used to evaluate SOA predictions.

Aircraft measurements include aircraft campaigns from Aerosol, Radiation, and Cloud Processes affecting Arctic Climate (ARCPAC), Stratosphere-Troposphere Analyses of Regional Transport in 2008 (START08), California Nexus 2010 (CalNex), Arctic Research of the Composition of the Troposphere from Aircraft and Satellites (ARCTAS), and CCN measurements in China (CCN_China). ARCPAC (Brock et al., 2011) was conducted during March-April 2008 in the troposphere of the Alaskan Arctic, including particle size distributions, composition, and optical properties. START08 (Pan et al., 2010) was conducted during AprilJune 2008 to study the chemical and transport characteris- 
Table 2. Data sets for model evaluation.

\begin{tabular}{|c|c|}
\hline Species/variables & Data set (number of sites) \\
\hline $\begin{array}{l}\text { Cloud fraction (CF) } \\
\text { Cloud optical thickness (COT) } \\
\text { Cloud liquid water path (LWP) } \\
\text { Precipitating water vapor (PWV) } \\
\text { Aerosol optical depth (AOD) } \\
\text { Column cloud condensation nuclei (ocean) at } S=0.5 \% \text { (CCN5) }\end{array}$ & MODIS \\
\hline Cloud droplet number concentration (CDNC), LWP & Bennartz (2007) \\
\hline $\begin{array}{l}\text { Shortwave cloud radiative forcing (SWCF) } \\
\text { Longwave cloud radiative forcing (LWCF) } \\
\text { Downwelling longwave radiation at surface (FLDS) } \\
\text { Downwelling shortwave radiation at surface (FSDS) }\end{array}$ & CERES-EBAF \\
\hline Outgoing longwave radiation (OLR) & NOAA/CDC \\
\hline Carbon monoxide (CO) & East Asia: NIESJ (2133), TAQMN (70), KMOE (258) \\
\hline Ozone $\left(\mathrm{O}_{3}\right)$ & $\begin{array}{l}\text { CONUS: CASTNET (141) } \\
\text { Europe: Airbase (3846), BDQA (490), EMEP (317) } \\
\text { East Asia: TAQMN (70), KMOE (258) }\end{array}$ \\
\hline Sulfur dioxide $\left(\mathrm{SO}_{2}\right)$ & $\begin{array}{l}\text { CONUS: CASTNET (141) } \\
\text { Europe: Airbase (3846), BDQA (490), EMEP (317) } \\
\text { East Asia: MEPC (84), NIESJ (2133), KMOE (258), TAQMN (70) }\end{array}$ \\
\hline Nitric acid $\left(\mathrm{HNO}_{3}\right)$ & CONUS: CASTNET (141); Europe: EMEP (317) \\
\hline Ammonia $\left(\mathrm{NH}_{3}\right)$ & Europe: Airbase (3846), EMEP (317) \\
\hline Nitrogen dioxide $\left(\mathrm{NO}_{2}\right)$ & $\begin{array}{l}\text { CONUS: ARS (25877) } \\
\text { Europe: Airbase (3846), BDQA (490), EMEP (317) } \\
\text { East Asia: NIESJ, TAQMN, KMOE }\end{array}$ \\
\hline Sulfate $\left(\mathrm{SO}_{4}^{2-}\right)$, ammonium $\left(\mathrm{NH}_{4}^{+}\right)$, nitrate $\left(\mathrm{NO}_{3}^{-}\right)$ & $\begin{array}{l}\text { CONUS: CASTNET (141), IMPROVE (199), STN (18129); } \\
\text { Europe: Airbase (3846), EMEP (317) }\end{array}$ \\
\hline Chloride $\left(\mathrm{Cl}^{-}\right)$ & $\begin{array}{l}\text { CONUS: IMPROVE (199) } \\
\text { Europe: Airbase (3846), EMEP ( } 317)\end{array}$ \\
\hline Organic carbon $(\mathrm{OC})$ & CONUS: IMPROVE (199); Europe: EMEP (317) \\
\hline Black carbon (BC), total carbon (TC) & CONUS: IMPROVE (199), STN (18129) \\
\hline Formaldehyde (HCHO), isoprene (ISOP), and toluene (TOL) & CONUS: AQS (25877) \\
\hline $\begin{array}{l}\text { Hydrocarbon-like organic aerosol (HOA), oxygenated } \\
\text { organic aerosol (OOA), total organic aerosol (TOA) }\end{array}$ & $\begin{array}{l}\text { Northern Hemisphere: Zhang et al. (2007) and Jimenez et al. (2009) } \\
\text { (Z07 \& J09) (33) }\end{array}$ \\
\hline Secondary organic aerosol (SOA) & CONUS: Ohio (2) and California (2) (Lewandowski et al., 2013) \\
\hline Particulate matter with diameter less than and equal to $2.5 \mu \mathrm{m}\left(\mathrm{PM}_{2.5}\right)$ & $\begin{array}{l}\text { CONUS: IMPROVE (199), STN (18129) } \\
\text { Europe: BDQA (490), EMEP (317) }\end{array}$ \\
\hline Particulate matter with diameter less than and equal to $10 \mu \mathrm{m}\left(\mathrm{PM}_{10}\right)$ & $\begin{array}{l}\text { CONUS: AQS (25877) } \\
\text { Europe: Airbase (3846), BDQA (490), EMEP (317) } \\
\text { East Asia: MEPC (84), NIESJ (2133), KMOE (258), TAQMN (70) }\end{array}$ \\
\hline Column CO & Globe: MOPITT \\
\hline Column $\mathrm{NO}_{2}$, column $\mathrm{SO}_{2}$, column $\mathrm{HCHO}$, column glyoxal $\left(\mathrm{C}_{2} \mathrm{H}_{2} \mathrm{O}_{2}\right)$ & Globe: SCIAMACHY \\
\hline Tropospheric ozone residual (TOR) & Globe: OMI/MLS \\
\hline $\mathrm{O}_{3}, \mathrm{CO}, \mathrm{NO}_{x}$, and $\mathrm{NO}_{y}$ profiles & $\begin{array}{l}\text { ARCPAC (March-April, 2008), ARCTAS (April-June, 2008), } \\
\text { START08 (April-June, 2008), and CalNex (May-June, 2010) }\end{array}$ \\
\hline CCN_China & Beijing: Zhang et al. (2011) (July-September, 2008) \\
\hline \multicolumn{2}{|c|}{$\begin{array}{l}\text { NOAA/CDC: National Oceanic and Atmospheric Administration Climate Diagnostics Center; MODIS: Moderate Resolution Imaging Spectroradiometer; CERES-EBAF: Clouds and } \\
\text { Earth's Radiant Energy System-Energy Balanced and Filled product; MOPITT: the Measurements Of Pollution In The Troposphere; OMI/MLS: the Aura Ozone Monitoring Instrument in } \\
\text { combination with Aura Microwave Limb Sounder; SCIAMCHY: the SCanning Imaging Absorption spectroMeter for Atmospheric CHartographY; CASTNET: Clean Air Status and Trends } \\
\text { Network; IMPROVE: Interagency Monitoring of Protected Visual Environments; STN: Speciation Trends Network; AQS: Air Quality System; EMEP: European Monitoring and Evaluation } \\
\text { Program; BDQA: Base de Données sur la Qualité de l'Air; AirBase: European air quality database; MEPC: Ministry of Environmental Protection of China; TAQMN: Taiwan Air Quality } \\
\text { Monitoring Network; NIESJ: National Institute for Environmental Studies of Japan; KMOE: Korean Ministry of Environment; ARCPAC: Aerosol, Radiation, and Cloud Processes affecting } \\
\text { Arctic Climate in 2008 (Brock et al., 2011); ARCTAS: Arctic Research of the Composition of the Troposphere from Aircraft and Satellites (Jacob et al., 2010); START08: } \\
\text { Stratosphere-Troposphere Analyses of Regional Transport in } 2008 \text { (Pan et al., 2010); CalNex: California Nexus } 2010 \text { (Ryerson et al., 2013). }\end{array}$} \\
\hline
\end{tabular}


tics of the extratropical upper tropospheric and lower stratospheric region over central North America. CalNex (Ryerson et al., 2013) was conducted during May-July 2010 to provide improved scientific knowledge for emission control strategies to simultaneously address the interrelated issues of air quality and climate change. ARCTAS (Jacob et al., 2010) was conducted during April-June 2008 to investigate the chemistry of the Arctic's lower atmosphere. CCN_China (Zhang et al., 2011) was conducted over Beijing during JulySeptember 2008 to investigate the impacts of aerosols on cloud formation.

\subsection{Evaluation protocol}

The protocols for performance evaluation include spatial distributions and statistics, following the approach of Zhang et al. (2012b). The aircraft profile evaluation is based on the Atmospheric Model Working Group (AMWG) diagnostics package (Tilmes et al., 2015). Monthly mean model results are compared for corresponding regions and seasons of the field campaign. The analysis of the performance statistics will focus on mean bias (MB), normalized mean bias (NMB), normalized mean error (NME), and root mean square error (RMSE) defined by Yu et al. (2006) and Zhang et al. (2006). The radiative/cloud variables are evaluated annually, including outgoing longwave radiation (OLR) from NOAA/CDC; downwelling shortwave radiation (FSDS), downwelling longwave radiation (FLDS), shortwave cloud forcing (SWCF), and longwave cloud forcing (LWCF) from CERES-EBAF; cloud fraction (CF), aerosol optical depth (AOD), cloud optical thickness (COT), precipitating water vapor (PWV), and CCN from MODIS, as well as CDNC and LWP from Bennartz (2007). CDNC is calculated as an average value of layers between 850 and $960 \mathrm{hPa}$ for comparison with the satellite-derived values. Chemical concentrations evaluated include $\mathrm{CO}, \mathrm{O}_{3}, \mathrm{SO}_{2}$, ammonia $\left(\mathrm{NH}_{3}\right)$, $\mathrm{NO}_{2}$, nitric acid $\left(\mathrm{HNO}_{3}\right)$, VOCs (i.e., formaldehyde, isoprene, and toluene), particulate matter (PM) with diameter less than and equal to $10 \mu \mathrm{m}\left(\mathrm{PM}_{10}\right)$ and $2.5 \mu \mathrm{m}\left(\mathrm{PM}_{2.5}\right)$, and $\mathrm{PM}_{2.5}$ major components (e.g., $\mathrm{SO}_{4}^{2-}, \mathrm{NH}_{4}^{+}, \mathrm{NO}_{3}^{-}$, black carbon, $\mathrm{BC}$, organic carbon, $\mathrm{OC}$, and total carbon, TC) for CONUS and Europe. The chemical observations over East Asia are very limited, which only include surface observations of $\mathrm{CO}, \mathrm{SO}_{2}, \mathrm{NO}_{2}$, and $\mathrm{O}_{3}$ from Hong Kong, South Korea, and Japan, and $\mathrm{PM}_{10}$ over mainland China (derived from the air pollution index), Hong Kong, South Korea, and Japan. Since $\mathrm{PM}_{2.5}$ and $\mathrm{PM}_{10}$ are not explicit species simulated in MAM7, their concentrations are estimated based on size distributions of dry particles used in MAM7. The properties of the particle size distribution for MAM7 are summarized in Table S1 in the Supplement.

Column concentrations of tropospheric $\mathrm{CO}, \mathrm{NO}_{2}, \mathrm{HCHO}$, $\mathrm{C}_{2} \mathrm{H}_{2} \mathrm{O}_{2}$, and tropospheric $\mathrm{O}_{3}$ residual (TOR) are evaluated for the globe. The CO column evaluation follows the AMWG diagnostics approach, which applies $1^{\circ} \times 1^{\circ}$ monthly mean
Level 3 MOPITT a priori and averaging kernels to monthly mean model results to account for the a priori dependence and vertical resolution of the MOPITT data. The measured $\mathrm{NO}_{2}$ and $\mathrm{HCHO}$ columns are derived from the satellite retrievals from SCIAMCHY, which are monthly mean gridded data on a $0.25^{\circ} \times 0.25^{\circ}$ horizontal grid resolution for the period of 2008-2010. The measured glyoxal column is derived from the satellite retrievals from SCIAMCHY, which are monthly mean gridded data on a $0.125^{\circ} \times 0.125^{\circ}$ horizontal grid resolution for the period of 2008. The measured $\mathrm{O}_{3}$ is derived from the combing retrievals from the Aura Ozone Monitoring Instrument and Microwave Limb Sounder observations, which are monthly mean gridded data on a $1.25^{\circ} \times 1.25^{\circ}$ horizontal grid resolution for the period of 2008-2010.

All surface observational data used for evaluating 2008 2010 simulations are available throughout 2008-2010 except for several variables with data during a limited time period of 2001-2010 including OC from EMEP, SOA from Lewandowski et al. (2013), and OA from Zhang et al. (2007) and Jimenez et al. (2009). For one grid cell containing multiple observational sites, all the observations within the grid cell are averaged and compared to the simulated results in that grid cell. While using grid averaged observations helps reduce, to some extent, the uncertainties in comparing gridaveraged model output with pointwise observations, this approach cannot address the inherent uncertainties associated with the evaluation of the model results obtained at a coarse grid resolution.

\section{Model evaluations}

\subsection{Surface evaluation}

\subsubsection{Inorganic gases and aerosols}

Table 3 summarizes the performance statistics for major chemical species for CAM5-NCSU simulations with MOZART-4x and CB05_GE. Figure 1 shows the scatterplots between observations and model results. The statistical performances of MOZART-4x and CB05_GE are similar for most chemical species. As shown in Table 3, CO is underpredicted over East Asia by both MOZART-4x and CB05_GE, with NMBs of -65.6 and $-65.7 \%$, respectively. The underprediction of $\mathrm{CO}$ is mainly due to the underestimation of $\mathrm{CO}$ emissions from biomass burning (Tilmes et al., 2015). The underestimations in $\mathrm{CO}$ emissions lead to underpredictions of column $\mathrm{CO}$ concentrations, with NMBs of -25.8 and $-24.4 \%$ for MOZART-4x and CB05_GE, respectively. Both MOZART-4x and CB05_GE largely overpredict the concentrations of $\mathrm{SO}_{2}$ over CONUS (with NMBs of 580.2 and $561.6 \%$, respectively), East Asia (with NMBs of 47.0 and $35.5 \%$, respectively), and Europe (with NMBs of 100.9 and $94.1 \%$, respectively), likely due to the overestimation 
Table 3. Performance statistics of chemical species.

\begin{tabular}{|c|c|c|c|c|c|c|c|c|}
\hline \multirow[t]{2}{*}{ Species } & \multirow[t]{2}{*}{ Domain } & \multirow[t]{2}{*}{ Obs } & \multicolumn{3}{|c|}{ MOZART-4x } & \multicolumn{3}{|c|}{ CB05_GE } \\
\hline & & & Sim & $\operatorname{NMB}(\%)^{\mathrm{f}}$ & $\operatorname{NME}(\%)^{\mathrm{f}}$ & Sim & $\operatorname{NMB}(\%)^{\mathrm{f}}$ & $\operatorname{NME}(\%)^{\mathrm{f}}$ \\
\hline $\mathrm{CO}(\mathrm{ppb})$ & East Asia & 438.7 & 150.9 & -65.6 & 65.7 & 150.4 & -65.7 & 65.8 \\
\hline \multirow{3}{*}{$\mathrm{SO}_{2}^{\mathrm{a}}$} & CONUS & 1.7 & 11.6 & 580.2 & 580.2 & 11.2 & 561.6 & 561.6 \\
\hline & Europe & 4.7 & 9.5 & 100.9 & 121.2 & 9.2 & 94.1 & 115.4 \\
\hline & East Asia & 2.9 & 4.3 & 47.0 & 70.6 & 3.9 & 35.5 & 64.0 \\
\hline $\mathrm{NH}_{3}\left(\mu \mathrm{g} \mathrm{m}^{-3}\right)$ & Europe & 1.2 & 2.5 & 112.4 & 146.0 & 2.4 & 104.3 & 139.8 \\
\hline \multirow{3}{*}{$\mathrm{NO}_{2}^{\mathrm{b}}$} & CONUS & 8.3 & 4.0 & -51.4 & 55.9 & 4.0 & -52.2 & 56.4 \\
\hline & Europe & 17.4 & 6.7 & -61.4 & 65.5 & 6.6 & -62.1 & 66.0 \\
\hline & East Asia & 11.7 & 3.0 & -74.1 & 75.2 & 3.0 & -74.8 & 75.8 \\
\hline \multirow{3}{*}{$\mathrm{O}_{3}^{\mathrm{c}}$} & CONUS & 34.7 & 44.7 & 29.0 & 29.5 & 44.4 & 28.2 & 28.5 \\
\hline & Europe & 56.2 & 78.6 & 39.9 & 40.8 & 80.6 & 43.5 & 44.2 \\
\hline & East Asia & 29.8 & 48.3 & 62.4 & 62.4 & 47.7 & 60.3 & 60.3 \\
\hline \multirow{2}{*}{$\mathrm{HNO}_{3}\left(\mu \mathrm{g} \mathrm{m}^{-3}\right)$} & CONUS & 0.9 & 2.1 & 145.0 & 145.2 & 2.2 & 154.7 & 154.7 \\
\hline & Europe & 0.8 & 0.7 & -15.6 & 65.4 & 0.8 & -10.9 & 64.9 \\
\hline $\mathrm{HCHO}(\mathrm{ppb})$ & CONUS & 2.3 & 1.6 & -30.1 & 48.4 & 1.5 & -36.3 & 49.0 \\
\hline ISOP (ppb) & CONUS & 0.3 & 0.2 & -27.3 & 63.2 & 0.2 & -29.0 & 64.7 \\
\hline Toluene (ppb) & CONUS & 0.5 & 0.2 & -65.3 & 69.2 & 0.2 & -65.1 & 69.1 \\
\hline Col. CO $\left(\right.$ molec $\left.\mathrm{cm}^{-2}\right)$ & Globe & $1.6 \times 10^{18}$ & $1.2 \times 10^{18}$ & -25.8 & 27.5 & $1.2 \times 10^{18}$ & -24.4 & 26.1 \\
\hline Col. $\mathrm{NO}_{2}\left(\right.$ molec cm $\left.{ }^{-2}\right)$ & Globe & $5.5 \times 10^{14}$ & $8.5 \times 10^{14}$ & 56.0 & 71.0 & $9.3 \times 10^{14}$ & 70.2 & 83.3 \\
\hline Col. HCHO $\left(\right.$ molec $\left.^{-2}{ }^{-2}\right)$ & Globe & $4.6 \times 10^{15}$ & $3.1 \times 10^{15}$ & -31.2 & 39.2 & $3.1 \times 10^{15}$ & -32.7 & 40.4 \\
\hline Col. $\mathrm{C}_{2} \mathrm{H}_{2} \mathrm{O}_{2}\left(\right.$ molec $\left.\mathrm{cm}^{-2}\right)$ & Globe & $2.8 \times 10^{14}$ & $3.9 \times 10^{13}$ & -86.0 & 86.0 & $5.9 \times 10^{12}$ & -97.9 & -97.9 \\
\hline Col. $\mathrm{SO}_{2}(\mathrm{DU})$ & Globe & 1.2 & 0.3 & -70.1 & 90.1 & 0.3 & -73.5 & 88.7 \\
\hline TOR (DU) & Globe & 28.6 & 30.3 & 6.0 & 15.0 & 31.8 & 11.3 & 16.5 \\
\hline \multirow{2}{*}{$\mathrm{SO}_{4}^{2-}\left(\mu \mathrm{g} \mathrm{m}^{-3}\right)$} & CONUS & 1.8 & 3.0 & 72.9 & 72.9 & 3.3 & 89.7 & 89.7 \\
\hline & Europe & 1.8 & 2.9 & 62.1 & 70.1 & 3.2 & 79.7 & 85.2 \\
\hline \multirow{2}{*}{$\mathrm{NH}_{4}^{+}\left(\mu \mathrm{g} \mathrm{m}^{-3}\right)$} & CONUS & 0.9 & 1.3 & 37.8 & 49.9 & 1.3 & 44.3 & 55.6 \\
\hline & Europe & 0.9 & 1.3 & 51.5 & 63.1 & 1.4 & 63.4 & 72.8 \\
\hline \multirow{2}{*}{$\mathrm{NO}_{3}^{-}\left(\mu \mathrm{g} \mathrm{m}^{-3}\right)$} & CONUS & 0.9 & 0.9 & -6.0 & 44.4 & 0.7 & -21.2 & 40.2 \\
\hline & Europe & 1.7 & 1.2 & -28.9 & 54.2 & 1.2 & -30.5 & 53.4 \\
\hline \multirow{2}{*}{$\mathrm{Cl}^{-}\left(\mu \mathrm{g} \mathrm{m}^{-3}\right)$} & CONUS & 0.1 & 0.02 & -78.1 & 84.3 & 0.02 & -78.3 & 84.5 \\
\hline & Europe & 1.1 & 4.1 & 273.4 & 274.7 & 4.2 & 273.7 & 274.8 \\
\hline $\mathrm{BC}\left(\mu \mathrm{g} \mathrm{m}^{-3}\right)$ & CONUS & 0.3 & 0.2 & -29.3 & 44.6 & 0.2 & -29.3 & 44.6 \\
\hline \multirow{2}{*}{$\mathrm{OC}\left(\mu \mathrm{g} \mathrm{m}^{-3}\right)$} & CONUS & 0.9 & 1.0 & 2.1 & 33.2 & 0.7 & -20.7 & 32.8 \\
\hline & Europe & 2.9 & 0.7 & -74.2 & 77.3 & 0.7 & -75.1 & 78.0 \\
\hline $\mathrm{TC}\left(\mu \mathrm{g} \mathrm{m}^{-3}\right)$ & CONUS & 1.8 & 1.3 & -29.6 & 39.3 & 1.1 & -42.1 & 45.8 \\
\hline $\mathrm{SOA}^{\mathrm{d}}$ & CONUS & 1.8 & 1.8 & -1.9 & 29.3 & 1.4 & -23.1 & 35.8 \\
\hline $\mathrm{HOA}^{\mathrm{d}}$ & $\mathrm{N} . \mathrm{H}^{\mathrm{e}}$ & 2.1 & 0.5 & -77.2 & 81.5 & 0.5 & -76.7 & 81.3 \\
\hline $\mathrm{OOA}^{\mathrm{d}}$ & N.H. ${ }^{e}$ & 4.8 & 2.1 & -56.5 & 56.6 & 1.8 & -62.3 & 62.3 \\
\hline $\mathrm{TOA}^{\mathrm{d}}$ & N.H. ${ }^{e}$ & 7.9 & 2.5 & -67.8 & 68.2 & 2.3 & -71.2 & 72.0 \\
\hline \multirow{2}{*}{$\mathrm{PM}_{2.5}\left(\mu \mathrm{g} \mathrm{m}^{-3}\right)$} & CONUS & 7.4 & 10.3 & 38.9 & 58.1 & 10.3 & 37.7 & 58.6 \\
\hline & Europe & 14.4 & 11.5 & -20.4 & 48.4 & 11.8 & -18.3 & 47.0 \\
\hline \multirow{3}{*}{$\mathrm{PM}_{10}\left(\mu \mathrm{g} \mathrm{m}^{-3}\right)$} & CONUS & 20.6 & 12.6 & -38.6 & 50.2 & 12.6 & -38.9 & 50.7 \\
\hline & Europe & 22.1 & 18.8 & -14.9 & 39.9 & 19.2 & -13.1 & 38.9 \\
\hline & East Asia & 88.0 & 59.0 & -32.9 & 41.1 & 64.8 & -26.4 & 37.2 \\
\hline
\end{tabular}



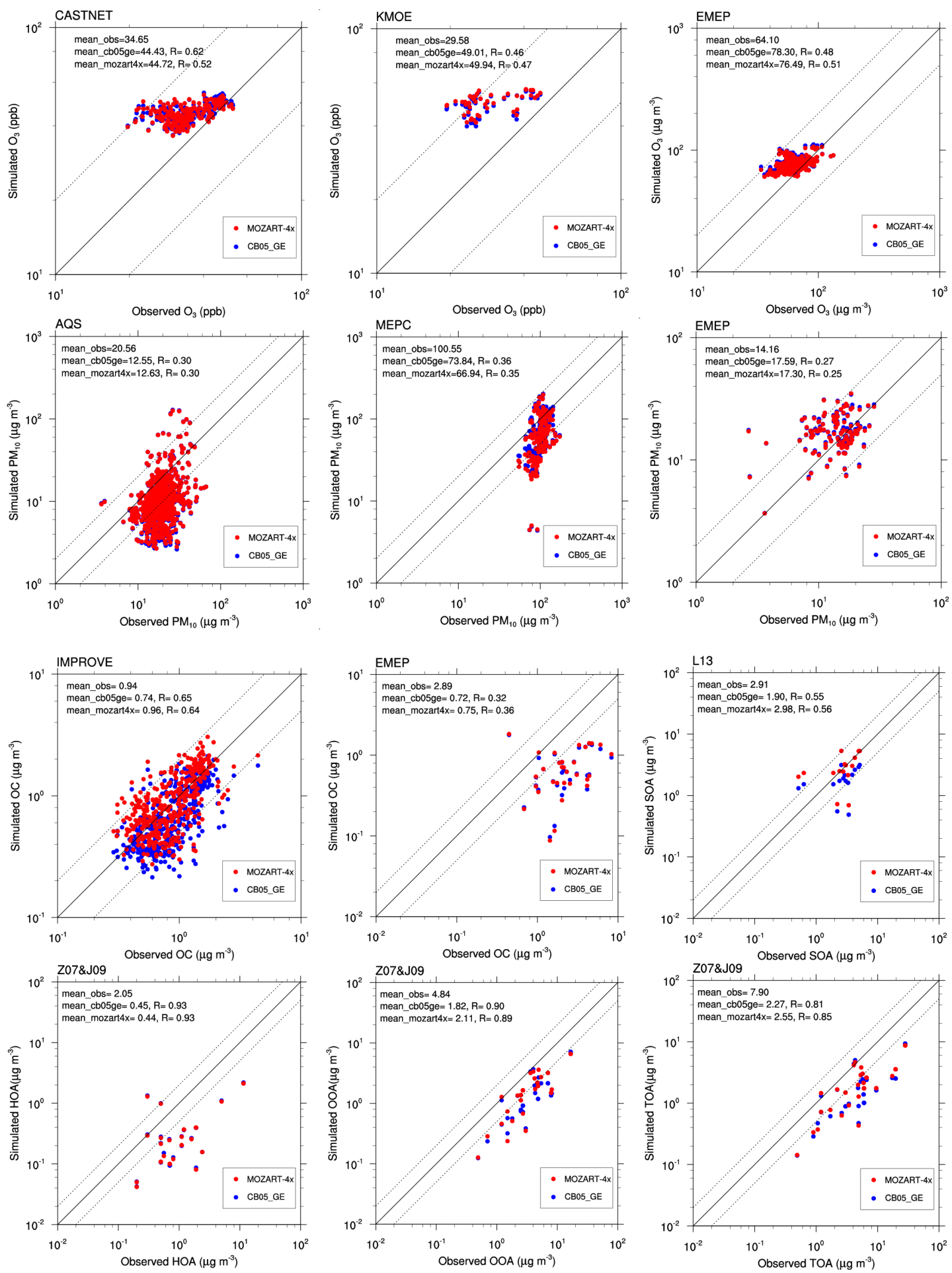

Figure 1. Scatterplots of $\mathrm{O}_{3}$, PM, organic carbon (OC), secondary organic aerosol (SOA), hydrocarbon-like organic aerosol (HOA), oxygenated organic aerosol (OOA), and total organic aerosol (TOA) over various sites during 2008-2010.

of $\mathrm{SO}_{2}$ emissions, the uncertainties in the emission injection heights, as well as the vertical mixing scheme used. For example, several modeling studies over East Asia reported that the underestimates of emissions of $\mathrm{SO}_{2}$ and $\mathrm{NO}_{x}$ are a main cause of poor model performance (e.g., Liu et al., 2010; Zhang et al., 2016a, b). The overpredictions of surface $\mathrm{SO}_{2}$ concentrations result in the overpredictions of the concentrations of $\mathrm{SO}_{4}^{2-}$ at the surface. The overpredictions of 
surface $\mathrm{SO}_{4}^{2-}$ concentrations can also be attributed to the uncertainties in the $\mathrm{OH}$ predictions. The air-mass weighted tropospheric mean $\mathrm{OH}$ concentrations predicted by MOZART$4 \mathrm{x}$ and CB05_GE are both $13.1 \times 10^{5} \mathrm{molec}^{-3}$, which is slightly higher than the present-day tropospheric mean $\mathrm{OH}$ level of $(11.1 \pm 1.6) \times 10^{5}$ molec $\mathrm{cm}^{-3}$ of Naik et al. (2013). The higher $\mathrm{OH}$ level can result in higher oxidation of $\mathrm{SO}_{2}$ to produce more $\mathrm{SO}_{4}^{2-}$. Surface $\mathrm{NH}_{3}$ concentrations from MOZART-4x and CB05_GE are overpredicted over Europe (with NMBs of 112.4 and $104.3 \%$, respectively), likely due to the overestimation of $\mathrm{NH}_{3}$ emissions. The overpredictions of the $\mathrm{NH}_{3}$ concentrations can potentially result in the overpredictions of the $\mathrm{NH}_{4}^{+}$concentrations at the surface. On the other hand, the overpredictions of the $\mathrm{NH}_{4}^{+}$concentrations at the surface are also related to the overpredictions of the concentrations of $\mathrm{SO}_{4}^{2-}$ at the surface. The concentrations of $\mathrm{NO}_{2}$ from MOZART-4x and CB05_GE are largely underpredicted over CONUS (with NMBs of -51.4 and $-52.2 \%$, respectively), Europe (with NMBs of -61.4 and $-62.1 \%$, respectively), and East Asia (with NMBs of -74.1 and $-74.8 \%$, respectively), which is likely due to the uncertainties in estimating total $\mathrm{NO}_{x}$ emissions and emission injection heights as well. As shown in Fig. 1, the concentrations of $\mathrm{O}_{3}$ from MOZART-4x and CB05_GE are overpredicted over CONUS (with NMBs of 29.0 and $28.2 \%$ over the CASTNET sites, respectively), Europe (with NMBs of 19.3 and $22.2 \%$ over the EMEP sites, respectively) and East Asia (with NMBs of 68.8 and $65.7 \%$ over the KMOE sites, respectively). This is likely due to less $\mathrm{O}_{3}$ titration resulting from the underpredictions of $\mathrm{NO}_{x}$, the dilution of $\mathrm{NO}_{x}$ emissions resulting from the use of a coarse grid resolution, as well as possible underestimates in $\mathrm{O}_{3}$ dry deposition. Martin et al. (2014) reported the uncertainties in $\mathrm{O}_{3}$ dry deposition associated with vegetation phenology in CAM-chem, which led to positive biases of $16 \mathrm{ppb}$ over the eastern US and $8 \mathrm{ppb}$ over Europe, respectively, for summertime surface $\mathrm{O}_{3}$. The overpredictions of $\mathrm{SO}_{4}^{2-}$ result in the underpredictions of $\mathrm{NO}_{3}^{-}$and $\mathrm{Cl}^{-}$, through thermodynamic equilibrium, and therefore overpredictions of $\mathrm{HNO}_{3}$ over CONUS. As more $\mathrm{NH}_{4}^{+}$is needed to neutralize $\mathrm{SO}_{4}^{2-}$, less $\mathrm{NH}_{4}^{+}$is available to neutralize $\mathrm{NO}_{3}^{-}$and $\mathrm{Cl}^{-}$, driving total nitrate and total chlorine to partition into the gas phase to produce more $\mathrm{HNO}_{3}$ and $\mathrm{HCl}$. Yu et al. (2005) also found that the model biases in total nitrate $\left(\mathrm{TNO}_{3}=\mathrm{HNO}_{3}+\mathrm{NO}_{3}^{-}\right)$predictions can be attributed to measurement errors in $\mathrm{SO}_{4}^{2-}$ and total ammonium $\left(\mathrm{TNH}_{4}=\mathrm{NH}_{3}+\mathrm{NH}_{4}^{+}\right)$as well as the inaccurate predictions in $\mathrm{SO}_{4}^{2-}$ and $\mathrm{TNH}_{4}$. In addition, Reff et al. (2009) suggested several sources of $\mathrm{Cl}^{-}$(e.g., biomass burning and wildfires), which are not included in this work. There are no anthropogenic $\mathrm{Cl}^{-}$emissions included in this work except from sea-salt emissions, which is calculated online in CESM/CAM5. Omission of additional chlorine emissions may also partly explain the underpredictions of $\mathrm{Cl}^{-}$ over CONUS. $\mathrm{HNO}_{3}$ is underpredicted over Europe, which is mainly due to the underpredictions of $\mathrm{NO}_{x}$. The concentration of $\mathrm{Cl}^{-}$is overpredicted over Europe, which is likely due to the uncertainties for the gas-particle partitioning over coarse modes (He and Zhang, 2014). Unlike the performance of $\mathrm{Cl}^{-}$over CONUS, which is only for fine $\mathrm{Cl}^{-}$(in Aitken, accumulation, fine sea-salt, and fine dust modes), the performance of $\mathrm{Cl}^{-}$over Europe is for fine and coarse $\mathrm{Cl}^{-}$(in all seven modes). As the thermodynamic equilibrium is not treated for coarse particles (the irreversible condensation of $\mathrm{HCl}$ is assumed to occur on the surface of coarse particles), it is likely that the model overpredicts coarse $\mathrm{Cl}^{-}$but underpredicts fine $\mathrm{Cl}^{-}$due to the missing sources. Both MOZART$4 \mathrm{x}$ and CB05_GE overpredict $\mathrm{PM}_{2.5}$ over CONUS; however, they underpredict $\mathrm{PM}_{10}$ over the AQS sites, with NMBs of -38.6 and $-38.9 \%$, respectively. The underpredictions of $\mathrm{PM}_{10}$ are mainly due to the inaccurate predictions of coarse particles. Both MOZART-4x and CB05_GE underpredict $\mathrm{PM}_{2.5}$ and $\mathrm{PM}_{10}$ over Airbase and BDQA sites; however, they overpredict $\mathrm{PM}_{10}$ by $3.14 \mu \mathrm{g} \mathrm{m}^{-3}$ (or by $22.2 \%$ ) and $3.43 \mathrm{\mu g} \mathrm{m}^{-3}$ (or by $24.2 \%$ ) over the EMEP sites, respectively, which is mainly due to the overpredictions of coarse particles (e.g., $\mathrm{Cl}^{-}$) over these sites and uncertainties in the sea-salt and dust emissions. Both MOZART-4x and CB05_GE underpredict $\mathrm{PM}_{10}$ by $33.61 \mu \mathrm{g} \mathrm{m}^{-3}$ (or by $33.4 \%$ ) and $26.71 \mu \mathrm{g} \mathrm{m}^{-3}$ (or by $26.6 \%$ ) over the MEPC sites in mainland China, respectively, which is mainly due to the uncertainties in the emissions in primary gases (e.g., $\mathrm{SO}_{2}, \mathrm{NO}_{x}, \mathrm{NH}_{3}$, and VOCs) and particulate species (e.g., $\mathrm{SO}_{4}^{2-}, \mathrm{BC}$, and POA). Granier et al. (2011) compared the regional emissions among different inventories and indicated large uncertainties in the emissions over China. For example, the differences of $\mathrm{BC}$ biomass burning emissions over China among different inventories can be as large as a factor of 2.1, and the differences of $\mathrm{SO}_{2}$ anthropogenic emissions can be as large as a factor of 1.8 .

\subsubsection{VOCs and organic aerosols}

VOC species such as HCHO, ISOP, and TOL are underpredicted over CONUS, likely due to the uncertainties in the biogenic emissions from MEGAN2.1, anthropogenic emissions (e.g., $\mathrm{HCHO}$ and TOL) and the chemical reactions as well as a coarse horizontal resolution used in this work. Both MOZART-4x and CB05_GE underpredict BC with NMBs of -29.3 and $-29.3 \%$, respectively. The underpredictions of $\mathrm{BC}$ are likely due to the underestimations of $\mathrm{BC}$ emissions, as well as uncertainties in the transport and wet removal by convection (Ma et al., 2013; Wang et al., 2013; Tilmes et al., 2015).

OC is slightly overpredicted with an NMB of $2.1 \%$ by MOZART-4x over CONUS, whereas it is moderately underpredicted with an NMB of $-20.7 \%$ by CB05_GE. OC is evaluated against observations at the IMPROVE sites, and SOA dominates OC at these sites for both simulations with MOZART4-x and CB05_GE, with SOA / OC ratios of 83.0 
and $59.6 \%$, respectively. Although no SOA measurements are available from IMPROVE for evaluation, the differences in OC predictions can be attributed to the differences in SOA predictions because of dominance of SOA in total OC. Compared to the SOA observations at the four sites in the US from Lewandowski et al. (2013), MOZART-4x underpredicts SOA by $0.03 \mu \mathrm{g} \mathrm{m}^{-3}$ (or by $1.9 \%$ ), whereas CB05_GE underpredicts SOA by $0.4 \mu \mathrm{g} \mathrm{m}^{-3}$ (or by $23.1 \%$ ). Note that the SOA statistics are calculated using only four pairs of seasonal mean values at four sites in the US where the observed SOA data are available during 2008-2010; they therefore may not be representative because of limited data used for calculation. Figure 2 compares simulated and observed SOA concentrations at the four sites. MOZART-4x predicts higher SOA than CB05_GE at all four sites, which reduces underpredictions at Cleveland and Medina, $\mathrm{OH}$, but increases overpredictions at Bakersfield and Pasadena, CA. This indicates a better capability of MOZART-4x to simulate SOA at sites with relatively high SOA concentrations $\left(\geq 1 \mu \mathrm{g} \mathrm{m}^{-3}\right)$ compared to CB05_GE despite its tendency to overpredict at sites with lower SOA levels. The higher SOA concentrations predicted by MOZART-4x can be attributed to the higher $\mathrm{OH}$ levels and higher biogenic emissions in MOZART-4x. However, the concentration of $\mathrm{OC}$ is largely underpredicted by both MOZART-4x and CB05_GE over Europe, with NMBs of -74.2 and $-75.1 \%$, respectively, indicating the uncertainties in the emissions of SOA precursors and SOA formation treatment. For example, the aqueous-phase oxidation of VOCs in clouds is not taken into account in this work, which, however, can contribute several percentages of SOA in some areas and seasons over Europe (Couvidat et al., 2013). The hydrocarbon-like organic aerosol (HOA) predicted by MOZART-4x and CB05_GE correlated well with the observations at 33 sites in the Northern Hemisphere (e.g., with correlation coefficients of 0.93 for both simulations), but the amount is largely underpredicted by both MOZART$4 \mathrm{x}$ and CB05_GE, with NMBs of -77.2 and $-76.7 \%$, respectively, indicating that the POA may be too volatile with the implementation currently in the model. Oxygenated organic aerosol (OOA), which is roughly equivalent to the sum of SOA and SVOA, is also largely underpredicted at the 33 sites by both MOZART-4x and CB05_GE, with NMBs of -56.5 and $-62.3 \%$, respectively. This is mainly due to the uncertainties in the oxidation rate and fragmentation rates as well as SOA formation treatment. The underpredictions of HOA and OOA result in an underprediction of total organic aerosol (TOA) by both MOZART-4x and CB05_GE, with NMBs of -67.8 and $-71.2 \%$, respectively.

\subsection{Chemical column evaluation}

Figure 3 shows the zonal mean of column concentrations of $\mathrm{CO}, \mathrm{HCHO}$, glyoxal, $\mathrm{NO}_{2}$, and TOR for June, July, and August during 2008-2010. In general, MOZART-4x and CB05_GE predict similar zonal mean profiles of these

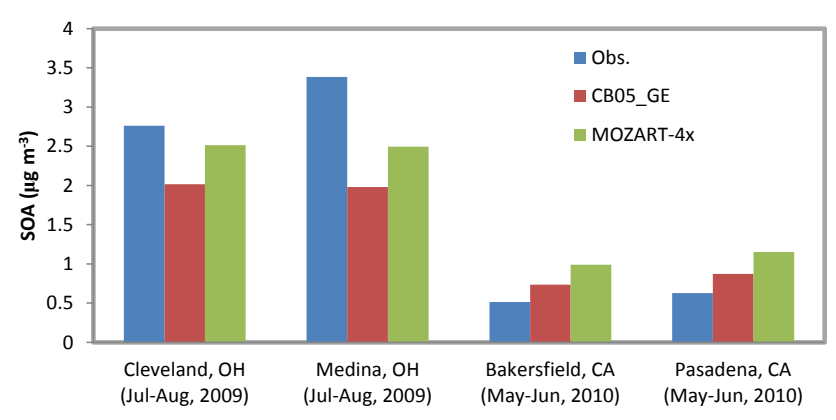

Figure 2. Comparisons of simulated and observed SOA concentrations at the four field study sites during 2009-2010. The observations are based on Lewandowski et al. (2013).

species. Both MOZART-4x and CB05_GE underpredict column $\mathrm{CO}$, due to a significant underestimation of $\mathrm{CO}$ emissions (Tilmes et al., 2015) and uncertainties in $\mathrm{OH}$ predictions. During summer, column $\mathrm{HCHO}$ is overpredicted over middle latitudes $\left(30-60^{\circ} \mathrm{N}\right)$ in the Northern Hemisphere and tropical regions $\left(0-10^{\circ} \mathrm{S}\right)$ in the Southern Hemisphere, while it is largely underpredicted over the rest of the regions. The underprediction of column $\mathrm{HCHO}$ is likely due to the uncertainties in the emissions of $\mathrm{HCHO}$ and its precursors as well as pathways for secondary $\mathrm{HCHO}$ formation. Both MOZART-4x and CB05_GE underpredict column glyoxal, with more underpredictions in CB05_GE. The underpredictions of glyoxal are mainly due to the uncertainties in the glyoxal chemical production and removal (Knote et al., 2014b). Several studies indicate that aromatics, isoprene, and ethyne are the major contributors to glyoxal formation (Washenfelder et al., 2011; Knote et al., 2014b). In MOZART-4x, glyoxal can be produced from photolysis of the oxidation products of toluene and oxidation products of aromatics (e.g., benzene, toluene, and xylenes), isoprene, and ethyne. CB05_GE does not include pathways for glyoxal production through photolysis, but includes glyoxal production from oxidation of alkenes (e.g., OLE, IOLE, ethene, and ISOP) and aromatics (e.g., toluene and xylenes). Uncertainties in the emissions of these precursors and the production pathways can propagate into the predicted glyoxal concentrations. MOZART-4x includes additional pathways for glyoxal production through photolysis and improved treatments for glyoxal production from additional oxidized VOC (e.g., benzene) products (Knote et al., 2014b), which can result in higher glyoxal than in CB05_GE. The major chemical loss of glyoxal includes photochemical loss and oxidation by $\mathrm{OH}$. The uncertainties in $\mathrm{OH}$ levels can propagate into glyoxal predictions as well. In addition, CB05_GE includes an additional pathway for glyoxal loss through its uptake by aerosols, which is not included in MOZART$4 \mathrm{x}$. This can explain in part the lower glyoxal concentrations predicted by CB05_GE than by MOZART-4x. An advanced treatment for glyoxal formation should therefore be 

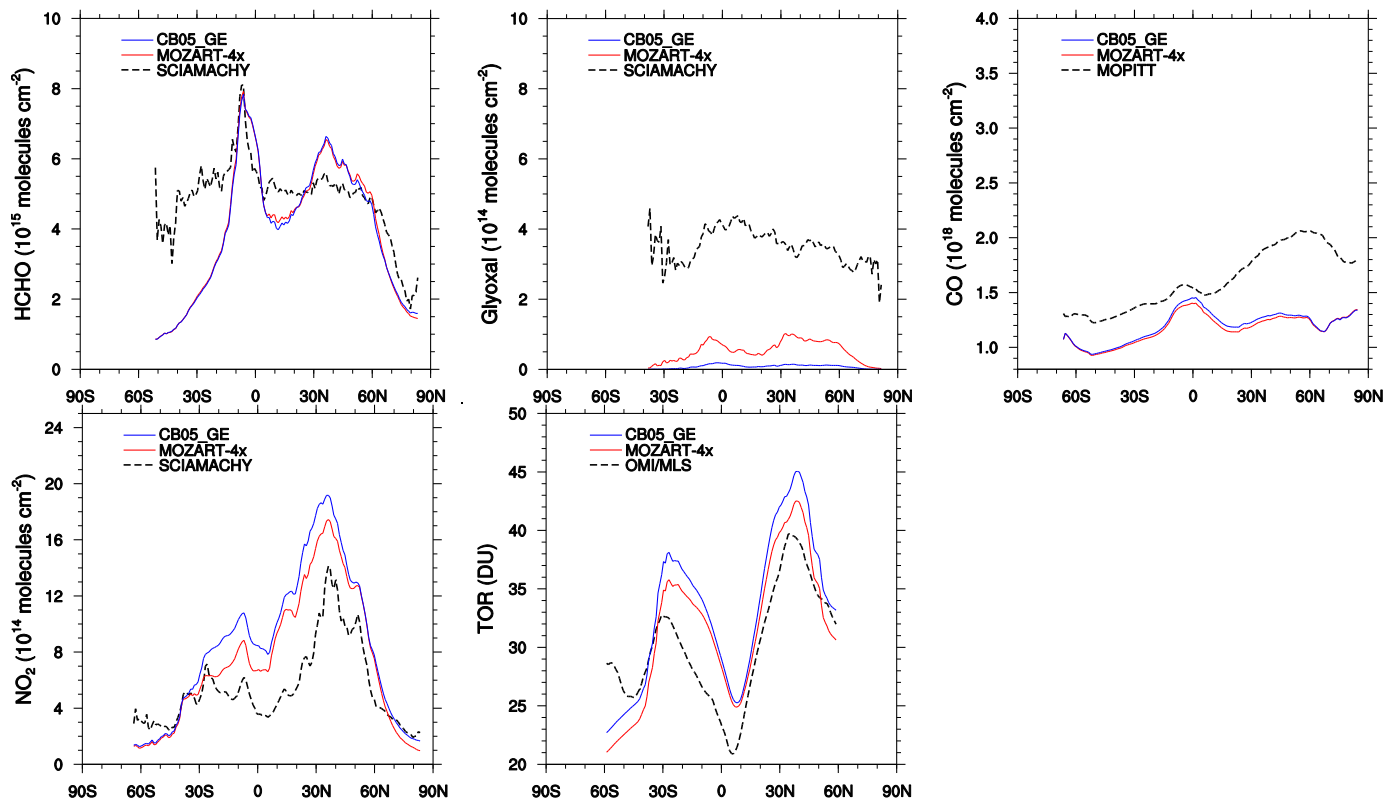

Figure 3. Zonal-mean profiles of $\mathrm{HCHO}$, glyoxal, $\mathrm{CO}, \mathrm{NO}_{2}$, and TOR from CB05_GE and MOZART-4x simulations for June, July, and August during 2008-2010.

developed in the future. Both MOZART-4x and CB05_GE overpredict column $\mathrm{NO}_{2}$, likely due to the uncertainties in the $\mathrm{NO}_{2}$ aircraft emissions and overpredictions of lightning $\mathrm{NO}_{x}$, as well as the satellite retrievals. The lightning $\mathrm{NO}_{x}$ emissions are calculated online (i.e., 6.2 and $6.4 \mathrm{Tg} \mathrm{N} \mathrm{yr}^{-1}$ in CB05_GE and MOZART-4x, respectively), which is about 1.2-2.2 $\mathrm{Tg} \mathrm{N} \mathrm{yr}^{-1}$ higher than that in Lamarque et al. (2012) and Tilmes et al. (2015). Tilmes et al. (2015) have shown that increased lightning $\mathrm{NO}_{x}$ emissions in CAM-chem can lead to an increase in $\mathrm{OH}$ levels and therefore a decrease in the lifetime of methane and an underestimation of $\mathrm{CO}$ in the model. As discussed in Yarwood et al. (2012), the errors in satellite $\mathrm{NO}_{2}$ retrievals are dominated by the atmospheric mass factor, which has a large uncertainty due to errors in the specification of clouds, surface albedo, a priori $\mathrm{NO}_{2}$ profile shape, and aerosols. Boersma et al. (2004) also reported that the error in the tropospheric $\mathrm{NO}_{2}$ retrievals is 35-60\%, especially over polluted areas. These can partly explain the overpredictions of column $\mathrm{NO}_{2}$. The higher zonal-mean concentrations of $\mathrm{NO}_{2}$ in CB05_GE than those in MOZART-4x are likely due to additional $\mathrm{NO}_{2}$ production from the reactions of VOCs with $\mathrm{NO}_{3}$ radicals in CB05_GE (e.g., reactions of $\mathrm{NO}_{3}$ with OLE, IOLE, and ethene). The zonal-mean distribution of summer TOR from CB05_GE is similar to that from MOZART-4x. TOR is overpredicted over $40^{\circ} \mathrm{S}-$ $50^{\circ} \mathrm{N}$ and underpredicted over $40-60^{\circ} \mathrm{S}$. The higher TOR from CB05_GE is mainly due to higher $\mathrm{O}_{3}$ production from higher $\mathrm{NO}_{2}$ and lower $\mathrm{O}_{3}$ loss from lower $\mathrm{OH}$ in $\mathrm{CB} 05$ _GE than in MOZART-4x.

\subsection{Vertical profile evaluation}

Figure 4 compares the vertical profile of major gases against the aircraft observations (i.e., ARCPAC, ARCTAS, START08, and CalNex). Compared with aircraft measurements, MOZART-4x and CB05_GE predict similar $\mathrm{O}_{3}$ and $\mathrm{CO}$ profiles, whereas there are large differences in $\mathrm{NO}_{x}$ (above $9 \mathrm{~km}$ ) and $\mathrm{NO}_{y}$ profiles (below $12 \mathrm{~km}$ ). $\mathrm{O}_{3}$ profiles from MOZART-4x and CB05_GE overall agree well with aircraft measurements, although $\mathrm{O}_{3}$ is slightly overpredicted near the surface. As discussed previously, the significant underpredictions of CO profiles in both MOZART$4 \mathrm{x}$ and CB05_GE are mainly due to the underestimations of $\mathrm{CO}$ biomass burning emissions and uncertainties in $\mathrm{OH}$ predictions. Both MOZART-4x and CB05_GE underpredict the vertical concentrations of $\mathrm{NO}_{x}$ at higher altitudes (e.g. above $9 \mathrm{~km}$ in ARCTAS and STRAT08), with a slightly better agreement in CB05_GE than in MOZART-4x. The concentrations of $\mathrm{NO}_{x}$ near the surface are slightly overpredicted by both simulations. The underpredictions of the concentrations of $\mathrm{NO}_{x}$ at higher altitudes are likely due in part to the uncertainties in the $\mathrm{NO}_{x}$ emissions, the chemical reactions of nitrogen cycles (e.g., heterogeneous reactions of $\mathrm{NO}_{2}$, $\mathrm{NO}_{3}$, and $\mathrm{N}_{2} \mathrm{O}_{5}$ over the surface of aerosol particles), the convection scheme, as well as the aircraft campaign data. Some field campaigns (e.g., ARCPAC) focus on the polluted regions with a significant contribution from biomass burning and local sources (Tilmes et al., 2015). The underestimations of emissions from these sources and uncertainties in the vertical mixing scheme can result in the underpredictions of their profiles. $\mathrm{NO}_{y}$ includes all the reactive nitrogen 

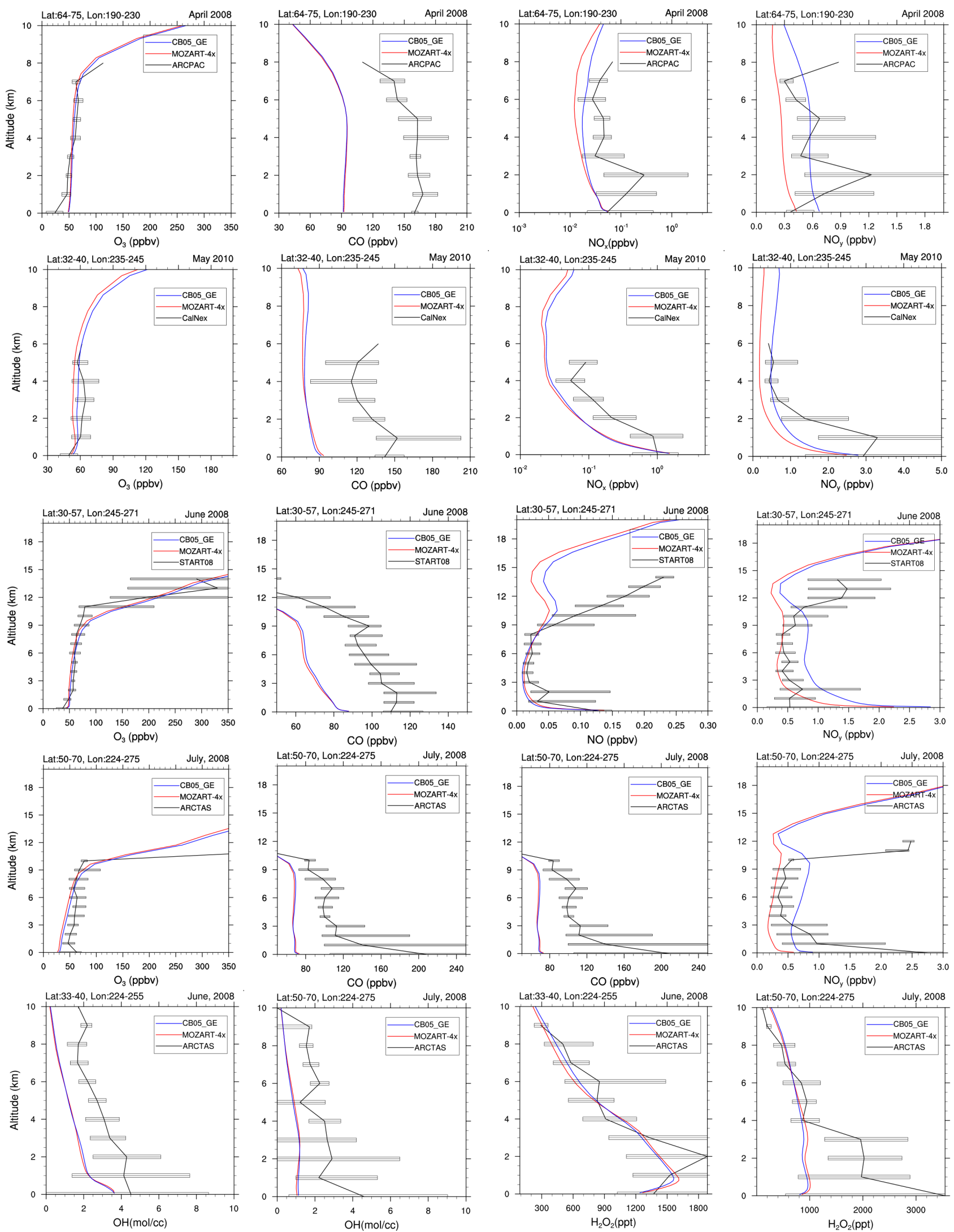

Figure 4. Simulated vertical profiles of $\mathrm{O}_{3}, \mathrm{CO}, \mathrm{NO}_{x}$, and $\mathrm{NO}_{y}$, against aircraft measurements. The black solid line represents observations from aircraft measurements (Pan et al., 2010; Brock et al., 2011; Ryerson et al., 2013; Jacob et al., 2010). The red solid and blue solid lines represent model output from MOZART-4x and CB05_GE, respectively. 
species. The simulated $\mathrm{NO}_{y}$ profiles from CB05_GE agree better with those observed during APCPAC, ARCTAS, and CalNex than those from MOZART-4x, whereas MOZART$4 \mathrm{x}$ predicts a slightly better $\mathrm{NO}_{y}$ profile against START08 in the lower troposphere than CB05_GE. OH concentrations are underpredicted by both MOZART-4x and CB05_GE against ARCTAS observations, whereas hydrogen peroxide $\left(\mathrm{H}_{2} \mathrm{O}_{2}\right)$ mixing ratios are well predicted above $4 \mathrm{~km}$ but underpredicted below $4 \mathrm{~km}$. Compared to CB05_GE, MOZART-4x predicts slightly higher $\mathrm{H}_{2} \mathrm{O}_{2}$ within $4 \mathrm{~km}$ above the surface. However, the performance here only represents the local conditions, instead of global conditions. Figure 5 compares the vertical profile of simulated $\mathrm{CCN}$ against the aircraft observations from CCN_China. Both MOZART-4x and CB05_GE slightly overpredict the CCN (at supersaturation of $0.2 \%$ ) profile over the Beijing area, with fewer overpredictions in MOZART-4x.

\subsection{Cloud/radiative evaluation}

Table 4 shows the statistical performance for major cloud/radiative variables for MOZART-4x and CB05_GE simulations. Radiative variables such as OLR, FSDS, and FLDS show excellent agreement with observations, with NMBs within $\pm 8 \%$ for both simulations. However, SWCF is overpredicted by both MOZART-4x and CB05_GE, with NMBs of 26.4 and $27.7 \%$, respectively, and LWCF is underpredicted by both MOZART-4x and CB05_GE, with NMBs of -21.6 and $-16.7 \%$, respectively. All predicted radiative variables show high correlation with observations, with correlation coefficients of 0.9 to 0.99 . CF is well predicted by MOZART-4x, with an NMB of $6.3 \%$, whereas CCN5, CDNC, COT, and LWP are moderately overpredicted or underpredicted, with NMBs of $-32.1,19.7,-26.0$, and $2.8 \%$, respectively. The performance of cloud variables is similar in CB05_GE, with NMBs of 6.0, -29.0, 20.8, -26.0, and $1.7 \%$ for CF, CCN5, CDNC, COT, and LWP, respectively. AOD is also underpredicted by both MOZART-4x and CB05_GE, with NMBs of -23.9 and $-24.6 \%$, respectively.

Figure 6 shows the Taylor diagram (Taylor, 2001) comparing the model performance of MOZART-4x with that of the CB05_GE for cloud and radiative predictions. The similarity between the two patterns is quantified in terms of their correlations (i.e., angle), their standard deviations (i.e., $y$ axis), and the ratio of their variances (i.e., $x$ axis). In general, the performances of major cloud/radiative variables between MOZART-4x and CB05_GE are similar. The major differences in the performance of cloud/radiative variables between MOZART-4x and CB05_GE are the variances of CCN5, CDNC, and SWCF, which are mainly due to the predicted aerosol distributions. The larger deviation of COT and LWP from observations (i.e., the two points located outside the diagram in Fig. 6) suggests the uncertainties both in the model treatments for cloud dynamics and thermodynamics as well as in the satellite retrievals.

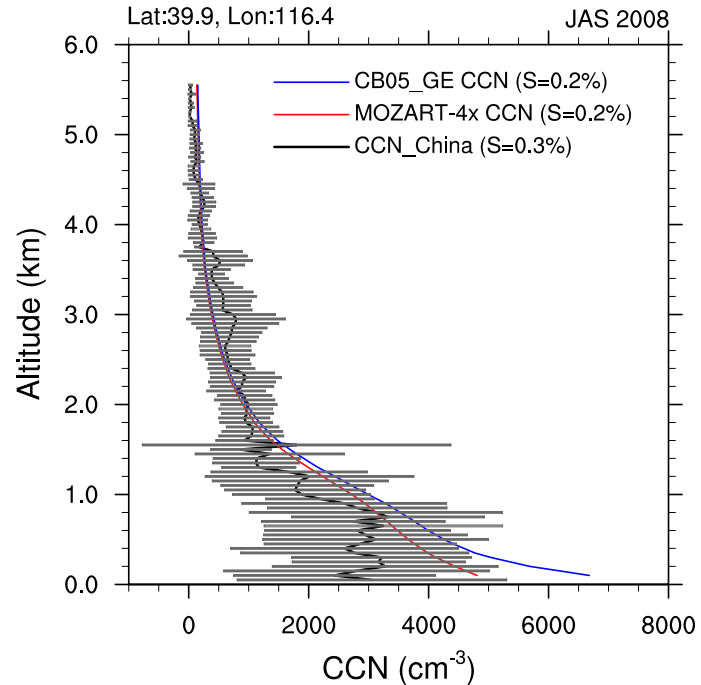

Figure 5. Simulated vertical profiles of CCN against aircraft measurements. The black solid line represents observations from aircraft measurements of Zhang et al. (2011). The red solid and blue solid lines represent model output from MOZART-4x and CB05_GE, respectively.

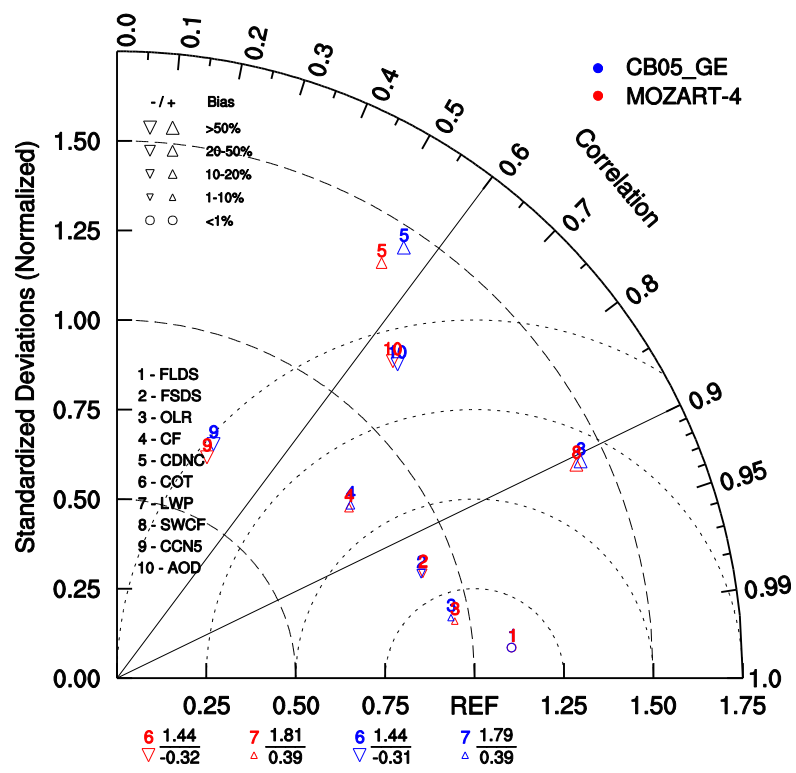

Figure 6. Taylor diagram of comparison of cloud and radiative predictions between MOZART-4x and CB05_GE.

Due to the underpredictions of cloud variables (e.g., COT and CCN5), OLR is slightly overpredicted by $7.8 \mathrm{~W} \mathrm{~m}^{-2}$ (or by $3.6 \%$ ) and LWCF is underpredicted by $4.8 \mathrm{~W} \mathrm{~m}^{-2}$ (or by $21.6 \%$ ) in MOZART-4x. Similarly, OLR is slightly overpredicted by $6.7 \mathrm{~W} \mathrm{~m}^{-2}$ (or by $3.1 \%$ ) and LWCF is underpredicted by $3.7 \mathrm{~W} \mathrm{~m}^{-2}$ (or by $16.7 \%$ ) in CB05_GE. Figure 7 shows the comparisons of satellite observations with model predictions for AOD, CCN5, CDNC, COT, and SWCF aver- 


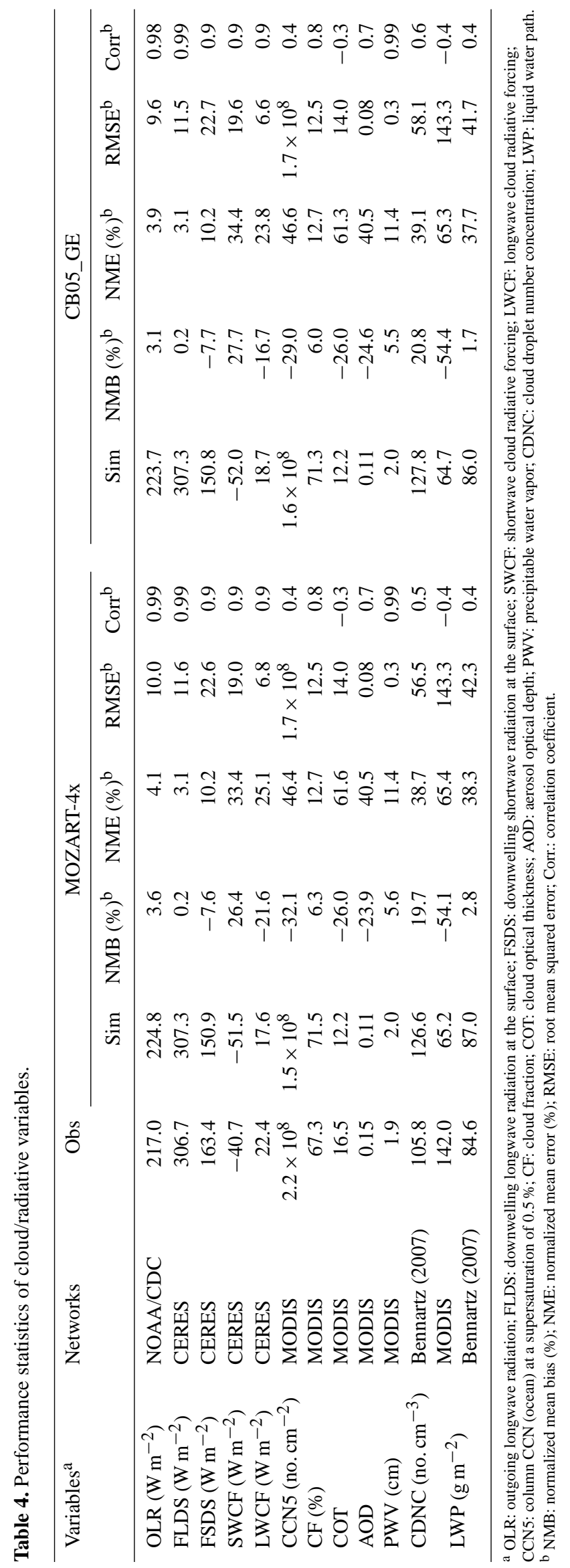



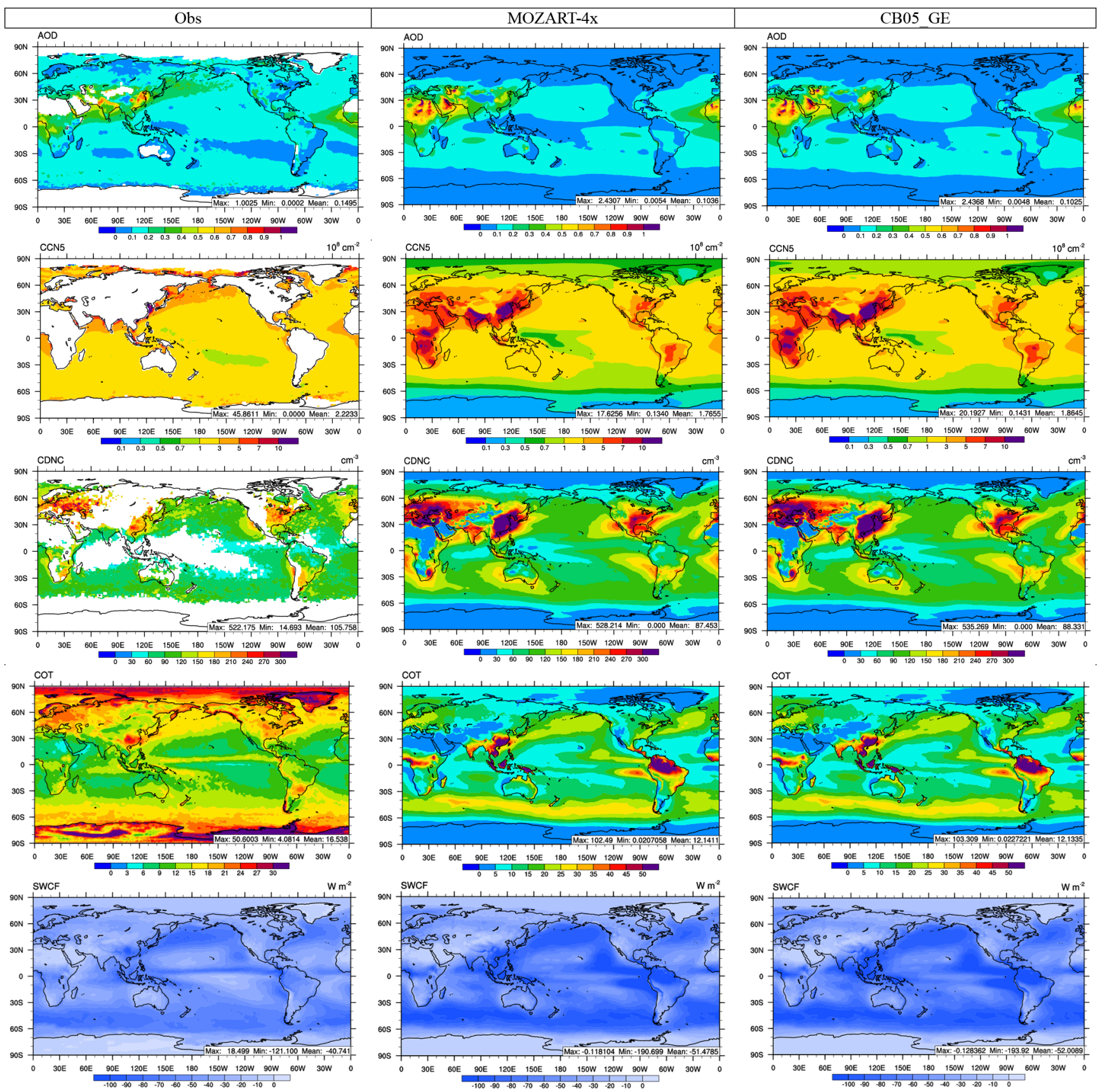

Figure 7. Comparison of satellite observations with predictions of AOD, CCN5, CDNC, COT, and SWCF by MOZART-4x and CB05_GE.

aged during 2008-2010. The underpredictions of AOD over oceanic areas can be attributed to the uncertainties in the sea-salt emissions and inaccurate predictions of other PM components (e.g., marine organic aerosols) over the ocean and overestimation of oceanic AOD in the MODIS collection 5.1 (Levy et al., 2013). The underprediction of AOD over land (e.g., tropical islands) is mainly due to the significant underestimation of biomass burning emissions in the model (Tilmes et al., 2015). AOD is higher in MOZART4x over most land areas (except East Asia and Europe) than in CB05_GE. The higher AOD in MOZART-4x is mainly due to higher SOA (e.g., over most land areas) and higher $\mathrm{NO}_{3}^{-}$(e.g., over CONUS) in MOZART-4x. The lower AOD over East Asia and Europe in MOZART-4x is mainly due to the lower $\mathrm{SO}_{4}^{2-}$ as there is an additional pathway of $\mathrm{SO}_{2}$ (oxidized by $\mathrm{O}_{3}$ ) included in $\mathrm{CB} 05$ _GE, although it is not included in MOZART-4x, and lower $\mathrm{NH}_{4}^{+}$to neutralize lower $\mathrm{SO}_{4}^{2-}$ through thermodynamic equilibrium. This additional pathway also results in higher $\mathrm{H}_{2} \mathrm{SO}_{4}$ predictions in CB05_GE and a higher aerosol number concentra- 
tion through homogeneous nucleation. Therefore, CCN5 is higher in CB05_GE than in MOZART-4x (see Fig. 7). CDNC is moderately overpredicted for both cases. Cloud droplet formation is sensitive to both particle number concentrations and updraft velocity (Reutter et al., 2009). The overprediction of CDNC is due partly to high activation fractions (e.g., inclusion of adsorption activation from insoluble $\mathrm{CCN}$ and the effective uptake coefficient of 0.06 used in this work) (Gantt et al., 2014) as well as the uncertainties in the model treatments for cloud microphysics (e.g., resolved clouds and subgrid-scale cumulus clouds) and satellite retrievals (e.g., error propagation of the input variables to derive CDNC) (Bennartz, 2007). COT is largely overpredicted over Southeast Asia and South America and underpredicted over polar regions for both simulations. Overpredictions in CDNC and COT can increase cloud albedo and, therefore, increase SWCF over the low and middle latitudes. The large underpredictions of COT over polar regions can be attributed to the uncertainties in plane-parallel visible-near-infrared retrievals with low solar zenith angle (Seethala and Horváth, 2010) and the influence of radiatively active snow on the overlying cloud fraction (Kay et al., 2012). Due to the different gas-phase mechanisms, the predicted SWCF (Fig. 7) and LWCF (figure not shown) are different, with a global average difference of 0.5 and $1.1 \mathrm{~W} \mathrm{~m}^{-2}$, respectively. However, the absolute differences in simulated SWCF can be as large as $13.6 \mathrm{~W} \mathrm{~m}^{-2}$, as shown in Fig. 7. The large differences of SWCF and LWCF between MOZART-4x and CB05_GE are mainly over subtropical regions (e.g., $20^{\circ} \mathrm{S}-20^{\circ} \mathrm{N}$ ), which is mainly due to lower COT in MOZART-4x than in CB05_GE.

\section{Model-to-model comparisons}

\subsection{Column comparisons}

\subsubsection{Column gases}

Figure $8 \mathrm{a}$ and $\mathrm{b}$ compares the column mass abundance of major gaseous and aerosol species simulated by MOZART-4x and CB05_GE. As shown in Fig. 8a, column CO predicted by MOZART-4x is about $2.4 \times 10^{20} \mathrm{~m}^{-2}$ (or $2.3 \%$ ) lower than that by CB05_GE in the global mean. The different column $\mathrm{CO}$ concentrations are due to different pathways for chemical production and loss of $\mathrm{CO}$ between MOZART-4x and CB05_GE, and different OH levels in MOZART-4x and CB05_GE. The chemical production of $\mathrm{CO}$ is mainly from photolysis and oxidation of VOCs species, and the chemical loss of $\mathrm{CO}$ is mainly from the oxidation by $\mathrm{OH}$. Different concentrations of VOC species can result in different chemical production of $\mathrm{CO}$. Meanwhile, the only chemical loss of $\mathrm{CO}$ in CB05_GE is the oxidation of $\mathrm{CO}$ by $\mathrm{OH}$, which produces $\mathrm{HO}_{2}$ and $\mathrm{CO}_{2}$. Higher $\mathrm{OH}$ levels in MOZART-4x can result in more CO loss. MOZART-4x includes an additional loss pathway of $\mathrm{CO}$ oxidized by $\mathrm{OH}$ to produce $\mathrm{CO}_{2}$ and $\mathrm{H}$. As a result, the combined rate constant for both pathways of $\mathrm{CO}$ oxidation by $\mathrm{OH}$ in MOZART-4x is about $4 \%$ higher than in CB05_GE. All these differences result in 2301 and $2265 \mathrm{Tg} \mathrm{yr}^{-1}$ chemical losses of CO in MOZART-4x and CB05_GE, respectively.

The global mean differences in the simulated column concentrations of $\mathrm{SO}_{2}$ and $\mathrm{NH}_{3}$ between MOZART-4x and CB05_GE are $2.0 \times 10^{18} \mathrm{~m}^{-2}$ (or $12.5 \%$ ) and $1.9 \times 10^{17} \mathrm{~m}^{-2}$ (or $3.1 \%$ ), respectively. The lower column abundance of $\mathrm{SO}_{2}$ in CB05_GE is mainly due to the additional pathway for $\mathrm{SO}_{2}$ loss through oxidation by $\mathrm{O}_{3}$ over the surface of dust particles, which is not included in MOZART$4 \mathrm{x}$. This pathway can produce more $\mathrm{SO}_{4}^{2-}$ and, therefore, more $\mathrm{NH}_{3}$ is partitioned into the particulate phase to form $\mathrm{NH}_{4}^{+}$, which can neutralize additional $\mathrm{SO}_{4}^{2-}$, resulting in lower column abundance of $\mathrm{NH}_{3}$ in CB05_GE. Both column concentrations of $\mathrm{NO}_{x}$ and $\mathrm{NO}_{y}$ from MOZART-4x are about $9.4 \times 10^{17} \mathrm{~m}^{-2}$ (or $9.5 \%$ ) and $3.6 \times 10^{19} \mathrm{~m}^{-2}$ (or $46.3 \%$ ) lower than that from CB05_GE. The higher $\mathrm{NO}_{x}$ in CB05_GE is mainly due to the lower $\mathrm{OH}$ available for the chemical loss through the reaction of $\mathrm{NO}_{2}$ with $\mathrm{OH}$. $\mathrm{NO}_{y}$ in MOZART-4x includes $\mathrm{NO}_{x}, \mathrm{NO}_{3}$, nitrogen pentoxide $\left(\mathrm{N}_{2} \mathrm{O}_{5}\right), \mathrm{HNO}_{3}$, peroxynitric acid $\left(\mathrm{HO}_{2} \mathrm{NO}_{2}\right)$, chlorine nitrate $\left(\mathrm{ClONO}_{2}\right)$, bromine nitrate $\left(\mathrm{BrONO}_{2}\right)$, peroxyacetyl nitrate (PAN), organic nitrate (ONIT), methacryloyl peroxynitrate (MPAN), peroxy radical from the reaction of $\mathrm{NO}_{3}$ with ISOP (ISOPNO3), and lumped isoprene nitrate (ONITR), whereas $\mathrm{NO}_{y}$ in $\mathrm{CB} 05$ _GE includes $\mathrm{NO}_{x}$, $\mathrm{NO}_{3}, \mathrm{~N}_{2} \mathrm{O}_{5}, \mathrm{HNO}_{3}, \mathrm{HO}_{2} \mathrm{NO}_{2}, \mathrm{ClONO}_{2}, \mathrm{BrONO}_{2}$, nitrous acid (HONO), PAN, higher peroxyacyl nitrates (PANX), and organic nitrate (NTR). The reactions for reactive nitrogen species are different in MOZART-4x and CB05_GE, resulting in different $\mathrm{NO}_{y}$ predictions. Figure $\mathrm{S} 1$ in the Supplement shows the dominant species in $\mathrm{NO}_{y}$ predicted by the simulations using both MOZART-4x and CB05_GE. As shown in Fig. $\mathrm{S} 1, \mathrm{NO}_{x}, \mathrm{HNO}_{3}$, and TPAN (PAN+MPAN for MOZART-4x and PAN+PANX for CB05_GE) are the major components for $\mathrm{NO}_{y}$ concentrations, with the ratios of 90.5 and $91.7 \%$, respectively, for the sum of the mixing ratios of the top three species to that of $\mathrm{NO}_{y} . \mathrm{NO}_{x}$ dominates over East Asia, the eastern US, and western Europe, whereas TPAN dominates over most oceanic areas. Figure $S 2$ in the Supplement shows the absolute and relative differences for major $\mathrm{NO}_{y}$ species between MOZART-4x and CB05_GE. As shown in Fig. S2, MOZART-4x predicts lower column TPAN by $2.9 \times 10^{19}$ molecules $\mathrm{m}^{-2}$ (or by $63.4 \%$ ), which dominates the differences in $\mathrm{NO}_{y}$ predictions between the two simulations. The differences in TPAN predictions can be attributed to the differences in the kinetic reactions. Table S2 in the Supplement lists the reactions involving TPAN. As shown in Table S2, besides the differences in the reaction rate calculation, MOZART-4x includes one additional reaction, i.e., PAN destruction by $\mathrm{OH}$, which is not included in CB05_GE. In addition, simulated $\mathrm{OH}$ levels are higher in MOZART-4x than those in CB05_GE, which could result in 

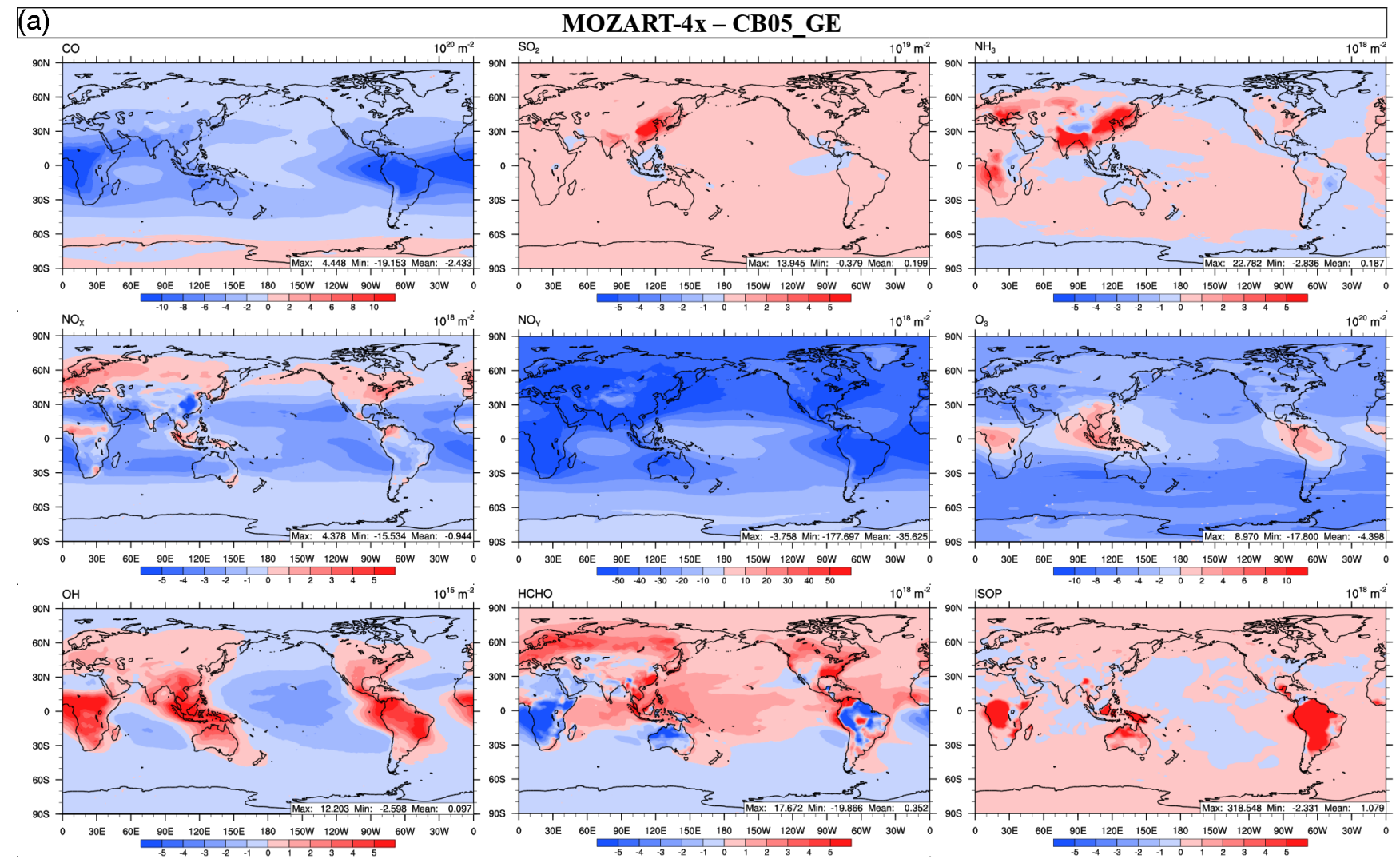

Figure 8.

more TPAN loss through oxidation by $\mathrm{OH}$. These differences can explain the lower TPAN mixing ratios in MOZART-4x than those in CB05_GE and thus lower column $\mathrm{NO}_{y}$ mass abundances in MOZART-4x than those in CB05_GE. Table S3 in the Supplement lists the $\mathrm{NO}_{y}$ species used in the calculation for Fig. 4 and other $\mathrm{NO}_{y}$-related comparisons. Figure S3 in the Supplement shows the absolute differences in $\mathrm{NO}_{y}$ (with and without inclusion of aerosol nitrate) between MOZART-4x and CB05_GE. If aerosol nitrate is accounted for in the $\mathrm{NO}_{y}$ definition, the differences in $\mathrm{NO}_{y}$ between the two mechanisms decrease over East Asia, the eastern US, Europe, and middle Africa as aerosol nitrate is higher in MOZART-4x over these regions (see Fig. 6b). For the rest of the areas, the differences in $\mathrm{NO}_{y}$ between the two mechanisms increase if aerosol nitrate is accounted for in the $\mathrm{NO}_{y}$ definition. The tropospheric column $\mathrm{O}_{3}$ from MOZART-4x is about $1.5 \mathrm{DU}$ (or by $4.7 \%$ ) lower than that from CB05_GE. Table 5 shows the tropospheric $\mathrm{O}_{3}$ budget from MOZART$4 \mathrm{x}$ and CB05_GE. The burdens of tropospheric $\mathrm{O}_{3}$ from MOZART-4x and CB05_GE are 325 and 333 Tg, respectively, which is comparable to the previous studies using CAM (Lamarque et al., 2012; Young et al., 2013). The $\mathrm{O}_{3}$ burden from MOZART-4x in this work is about $12 \mathrm{Tg}$ (or $3.8 \%$ ) higher than that in Tilmes et al. (2015), which is mainly due to the additional kinetic reactions included in this version of MOZART-4x. The dry deposition flux of $\mathrm{O}_{3}$ from MOZART-4x is $679 \mathrm{Tg} \mathrm{yr}^{-1}$, which is about $3.7 \%$ lower than that from CB05_GE (i.e., $705 \mathrm{Tg} \mathrm{yr}^{-1}$ ). The lower $\mathrm{O}_{3}$ dry deposition flux is mainly due to the lower $\mathrm{O}_{3}$ concentration simulated by MOZART-4x. The $\mathrm{O}_{3}$ chemical production and loss from CB05_GE and MOZART-4x are roughly within the range of Young et al. (2013). The $\mathrm{O}_{3}$ chemical production from MOZART-4x is comparable to that of Lamarque et al. (2012), but the $\mathrm{O}_{3}$ chemical production from CB05_GE is about $12.8 \%$ higher than Lamarque et al. (2012). In this table, chemical production is calculated mainly from reactions of $\mathrm{NO}$ with peroxy radicals and chemical loss is calculated mainly from the oxygen radical in the reaction of excited oxygen atoms $\left(\mathrm{O}^{1} \mathrm{D}\right)$ with water vapor $\left(\mathrm{H}_{2} \mathrm{O}\right)$ and from the reactions of $\mathrm{O}_{3}$ with the $\mathrm{HO}_{2}, \mathrm{OH}$, and alkenes. Different peroxy radicals and alkenes treated and different reaction rates used in the two mechanisms can contribute to the different chemical production and chemical loss of $\mathrm{O}_{3}$. The $\mathrm{O}_{3}$ lifetime is calculated based on the ratio of $\mathrm{O}_{3}$ burden to the total $\mathrm{O}_{3}$ loss (dry deposition + chemical loss). The $\mathrm{O}_{3}$ lifetime from $\mathrm{CB} 05$ _GE is comparable to those reported by Young et al. (2013), and the $\mathrm{O}_{3}$ lifetime from MOZART-4x is comparable to those reported by Lamarque et al. (2012) and Tilmes et al. (2015). 


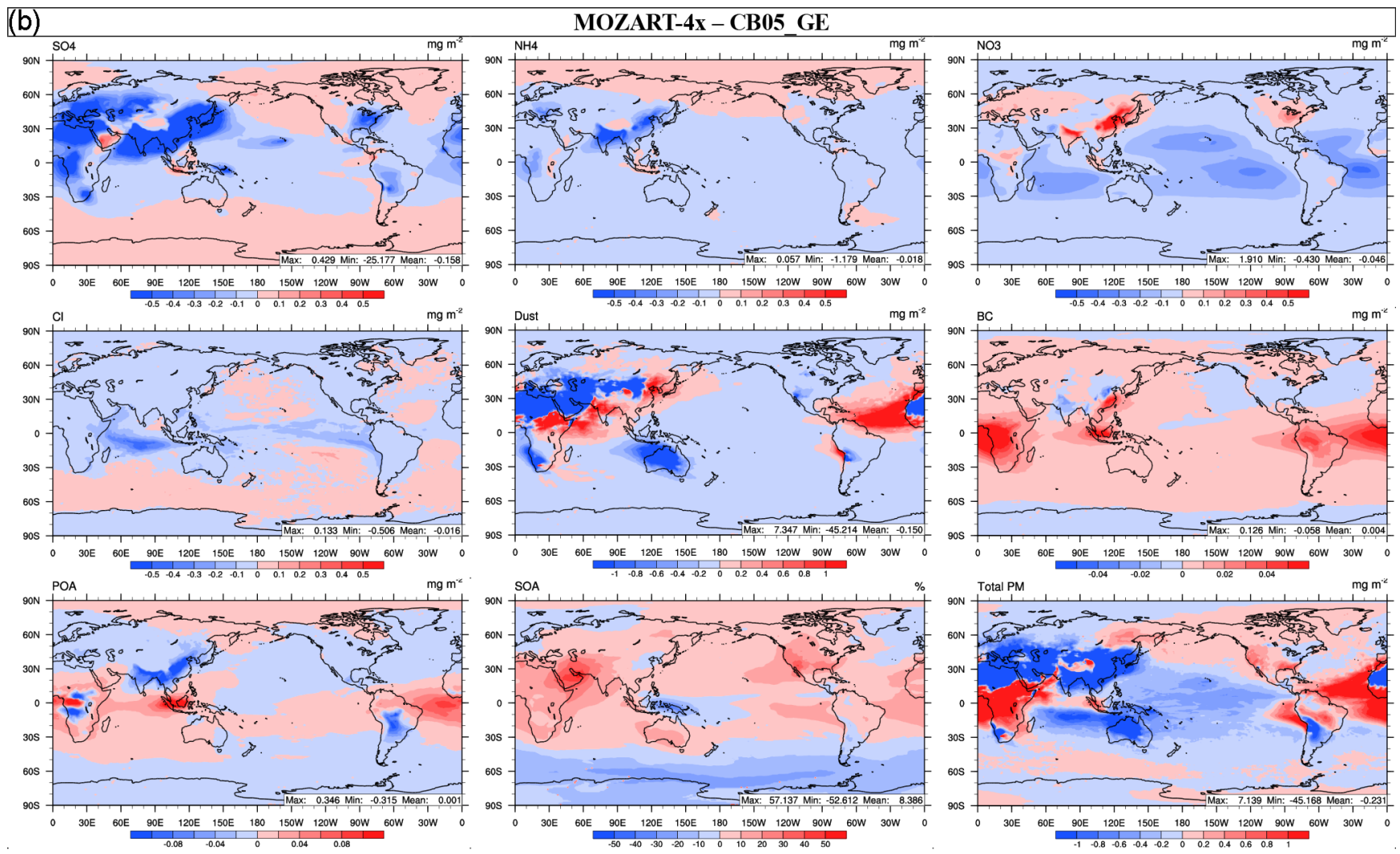

Figure 8. (a) Absolute differences averaged during 2008-2010 in tropospheric column concentrations of major gaseous species between MOZART-4x and CB05_GE. (b) Absolute differences averaged during 2008-2010 in tropospheric column concentrations of major aerosol species between MOZART-4x and CB05_GE.

Table 5. Tropospheric ozone budget.

\begin{tabular}{lrrrr}
\hline Ozone & MOZART-4x & CB05_GE & $\begin{array}{r}\text { Lamarque et } \\
\text { al. (2012) }\end{array}$ & $\begin{array}{r}\text { Young et } \\
\text { al. (2013) }\end{array}$ \\
\hline Burden $(\mathrm{Tg})$ & 325 & 333 & 328 & $337 \pm 23$ \\
${\text { Dry deposition }\left(\mathrm{Tg} \mathrm{yr}^{-1}\right)}_{\text {Chemical production }^{\mathrm{a}}\left(\mathrm{Tg} \mathrm{yr}^{-1}\right)}^{679}$ & 705 & 705 & $1003 \pm 200$ \\
Chemical loss $^{\mathrm{b}}\left(\mathrm{Tg} \mathrm{yr}^{-1}\right)$ & 4974 & 5743 & 4897 & $5110 \pm 606$ \\
Lifetime (days) & 4259 & 5194 & 4604 & $4668 \pm 727$ \\
\hline
\end{tabular}

${ }^{a}$ Chemical production is mainly contributed by reactions of NO with peroxy radicals. ${ }^{b}$ Chemical loss is mainly contributed by the oxygen radical in the $\mathrm{O}\left({ }^{1} \mathrm{D}\right)+$ water $\left(\mathrm{H}_{2} \mathrm{O}\right)$ reaction and by the reactions of ozone with the hydroperoxyl radical $\left(\mathrm{HO}_{2}\right), \mathrm{OH}$, and alkenes.

Column concentrations of $\mathrm{OH}, \mathrm{HCHO}$, and ISOP from MOZART-4x are higher than CB05_GE, with global mean values of $9.7 \times 10^{13} \mathrm{~m}^{-2}$ (or by $0.8 \%$ ), $3.5 \times 10^{17} \mathrm{~m}^{-2}$ (or by $1.3 \%$ ), and $1.1 \times 10^{18} \mathrm{~m}^{-2}$ (or by $25.6 \%$ ), respectively. The higher column concentrations of $\mathrm{OH}$ and $\mathrm{HCHO}$ are likely due to the photolysis of more peroxide species, better $\mathrm{HO}_{x}$ recycling, and higher precursors for secondary $\mathrm{HCHO}$ (e.g., ISOP) in MOZART-4x. MOZART-4x includes detailed organic peroxide species, whereas in CB05_GE, all the organic peroxide species are lumped into one species (i.e.,
$\mathrm{ROOH})$. The uncertainties in $\mathrm{HO}_{x}$ recycling in CB05_GE can also result in uncertainties in $\mathrm{OH}$ predictions. The higher ISOP is mainly due to higher biogenic emissions and less chemical loss in MOZART-4x than that in CB05_GE. In MOZART-4x, the chemical loss of ISOP is mainly from the oxidation of ISOP by $\mathrm{OH}, \mathrm{O}_{3}$, and $\mathrm{NO}_{3}$. However, in CB05_GE, the chemical loss of ISOP includes not only the oxidation of ISOP by $\mathrm{OH}, \mathrm{O}_{3}$, and $\mathrm{NO}_{3}$, but also the consumption of ISOP by atomic oxygen (i.e., O), $\mathrm{NO}_{2}$, and chlorine. 


\subsubsection{Column aerosols}

As shown in Fig. 8b, the differences in the domain average column mass abundances of most aerosol species (e.g., $\mathrm{NH}_{4}^{+}$, $\mathrm{BC}, \mathrm{Cl}^{-}$, and POA) between MOZART-4x and CB05_GE are within $\pm 0.02 \mathrm{mg} \mathrm{m}^{-2}$. The differences in the column $\mathrm{SO}_{4}^{2-}$ vary from -25.2 to $0.4 \mathrm{mg} \mathrm{m}^{-2}$, with the global mean of $-0.2 \mathrm{mg} \mathrm{m}^{-2}$. The simulated column concentrations of $\mathrm{SO}_{4}^{2-}$ from MOZART-4x are much lower than those from CB05_GE over East Asia, western Europe, and central Africa. $\mathrm{SO}_{2}$ can be oxidized by $\mathrm{O}_{3}$ to form $\mathrm{SO}_{4}^{2-}$ on the surface of dust particles in CB05_GE, which explains additional formation of $\mathrm{SO}_{4}^{2-}$ by $\mathrm{CB} 05$ _GE over these regions. The differences in the spatial distributions and magnitudes in the column concentrations of $\mathrm{NH}_{4}^{+}$are similar to those of $\mathrm{SO}_{4}^{2-}$ over land areas, which is associated with thermodynamic equilibrium. The column concentrations of $\mathrm{NO}_{3}^{-}$simulated by MOZART-4x are higher over East Asia, India, and Europe than those by CB05_GE, which is mainly due to its competition with $\mathrm{SO}_{4}^{2-}$ in forming ammonium salts in the particulate phase in those regions where the column $\mathrm{NH}_{3}$ concentrations are high (Fig. 8a). Dust emissions are very sensitive to the wind speed. Slight changes in wind speeds can result in a significant change in dust emissions and, thus, dust concentrations.

The column concentrations of SOA predicted by MOZART-4x are about $0.18 \mathrm{mg} \mathrm{m}^{-2}$ (or $8.4 \%$ ) higher than those predicted by CB05_GE. The higher SOA column concentrations are mainly over most continental areas in the middle and low latitudes. The SOA mainly includes biogenic SOA, anthropogenic SOA, and semi-volatile SOA. The differences in SOA are mainly due to the higher BVOC emissions and higher $\mathrm{OH}$ levels in MOZART-4x than in CB05_GE. Different branching ratios used in MOZART-4x and CB05_GE can also contribute to the different SOA predictions. MOZART-4x includes explicit species and more types of precursors for alkylperoxy radicals $\left(\mathrm{RO}_{2}\right)$, and different reaction rate constants for different reactions, whereas in CB05_GE, all oxidized VOCs are lumped as one species (i.e., $\mathrm{RO}_{2}$ ) and branching ratios are estimated based on the only three reactions (i.e., reactions of $\mathrm{RO}_{2}$ with $\mathrm{NO}, \mathrm{HO}_{2}$, and $\mathrm{RO}_{2}$ ). These differences can contribute to the differences in the estimation of branching ratios and, therefore, affect the partitioning between organic gas and aerosols through the 1.5 D VBS treatment implemented in CAM5-NCSU.

\subsection{SOA comparisons}

Figure 9 shows the contributions to total SOA (TSOA) concentrations from anthropogenic sources (ASOA), biogenic sources (BSOA), glyoxal (GLSOA), and semi-volatile organic aerosol (SVSOA) over Australia, Europe, North America, South Africa, South America, and East Asia over 20082010. The contributions of ASOA to TSOA predicted by MOZART-4x and CB05_GE are about 17-44, and 10-47\%,

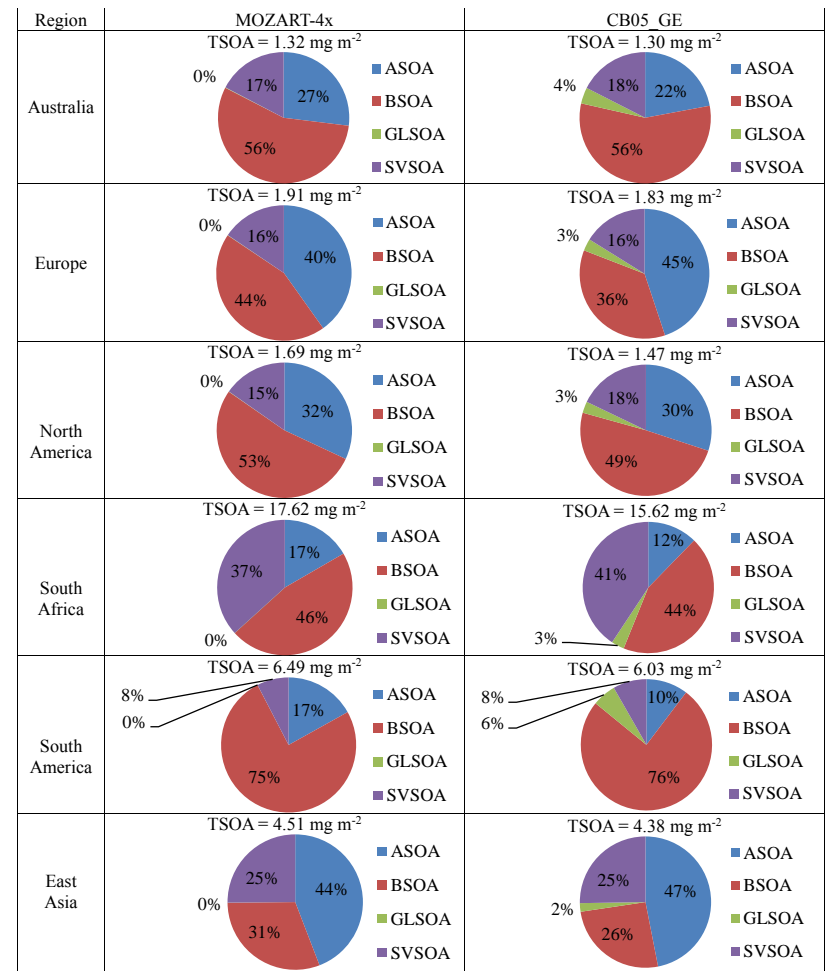

Figure 9. Column abundances $\left(\mathrm{mg} \mathrm{m}^{-2}\right)$ averaged during 20082010 of secondary organic aerosols (SOA) from anthropogenic sources (ASOA), biogenic sources (BSOA), and glyoxal (GLSOA), and semi-volatile organic aerosol (SVSOA) over Australia, Europe, North America, South Africa, South America, and East Asia.

respectively, with South America the least and East Asia the most. The contributions of BSOA to TSOA predicted by MOZART-4x and CB05_GE are about 31-75, and 26$76 \%$, respectively, with East Asia the least and South America the most. The contribution of GLSOA to TSOA predicted by CB05_GE is about 2-6\%.CB05_GE used in this work includes a simple conversion of glyoxal to condensable VOCs, which can be taken up by preexisting particles to form SOA. However, this conversion is not included in MOZART-4x. Therefore, there is no GLSOA predicted by MOZART-4x despite it predicting higher glyoxal as shown in Fig. 3. The contributions of SVSOA to TSOA predicted by MOZART-4x and CB05_GE are about 8-37, and 8-41\%, respectively, with South America the least and South Africa the most. Among four types of SOA, both MOZART-4x and CB05_GE predict BSOA as the main contributor over most regions (e.g., Australia, North America, South Africa, and South America) and ASOA as the main contributor over East Asia, which is mainly due to the much higher anthropogenic emissions over East Asia. Europe is a different example. MOZART-4x predicts BSOA as the top contributor (44\%) and ASOA as the second largest contributor (40\%), whereas CB05_GE predicts ASOA as the top contributor $(45 \%)$ and BSOA as the second largest contributor $(36 \%)$. 
Both MOZART-4x and CB05_GE predict ASOA as the top contributor (46-59\%) for spring, fall, and winter, and BSOA as the top contributor (57 and $47 \%$, respectively) for summer over Europe. Since MOZART-4x predicts higher BSOA than CB05_GE, BSOA is dominant in MOZART-4x on the annual average. The higher BSOA from MOZART-4x than from CB05_GE is mainly due to the higher BVOCs emissions in MOZART-4x and higher OH levels in MOZART-4x. The total BVOC emission in MOZART-4x is about $2.5 \times$ $10^{-3} \mathrm{~kg} \mathrm{~m}^{-2} \mathrm{yr}^{-1}$, which is about $7.2 \times 10^{-5} \mathrm{~kg} \mathrm{~m}^{-2} \mathrm{yr}^{-1}$ (or $2.9 \%$ ) higher than CB05_GE. The higher BVOCs emissions in MOZART-4x are mainly due to the different species mapping for MEGAN emission calculations. The differences of SOA from biogenic alkenes between MOZART-4x and CB05_GE are MYRC and BCARY in MOZART-4x, and OCI, HUM, and TER in CB05_GE (as shown in Table 1). In CAM-chem that uses MOZART, MEGAN calculates all of the individual species and CAM-chem sums them up to map with the MOZART mechanism species. For example, MYRC emissions consist of myrcene and ocimene, BCARY emissions consist of beta-caryophyllene, alpha-bergamotene, beta-bisabolene, beta-farnescene, and alpha-humulene, and LIMON emissions consist of limonene, phellandrene, and terpinene. Therefore, the biogenic emissions for more types of VOCs in MOZART-4x are higher than those in CB05_GE, resulting in higher BSOA in MOZART-4x. The differences in SOA from aromatics between MOZART-4x and CB05_GE are BENZENE in MOZART-4x and PAH in CB05_GE (as shown in Table 1). The emissions of PAH are higher over Europe, East Asia, the eastern US, and South Africa. The benzene emissions are about 1 order of magnitude higher than the emissions of PAH, and the rate constant of the oxidation of benzene by $\mathrm{OH}$ is temperature-dependent, whereas it is constant for oxidation of PAH by $\mathrm{OH}$. In addition, $\mathrm{OH}$ levels are higher in MOZART-4x than those in CB05_GE. These differences could result in different ASOA between two simulations. Both MOZART-4x and CB05_GE predict higher SVSOA contributions over South Africa than other regions, which is mainly due to the higher POA emissions (e.g., biomass burning) over this region.

Although the percentage contributions of different types of SOA predicted by MOZART-4x and CB05_GE are similar over most regions, the absolute mass concentrations of different types of SOA are different. For example, TSOA predicted by MOZART-4x is about $0.02-2.0 \mathrm{mg} \mathrm{m}^{-2}$ higher than by CB05_GE over these regions. ASOA predicted by MOZART-4x is about $0.068-1.017 \mathrm{mg} \mathrm{m}^{-2}$ higher than predicted by CB05_GE over most regions except Europe $\left(0.054 \mathrm{mg} \mathrm{m}^{-2}\right.$ lower) and East Asia $\left(0.062 \mathrm{mg} \mathrm{m}^{-2}\right.$ lower). BSOA predicted by MOZART-4x is about $0.162-$ $1.365 \mathrm{mg} \mathrm{m}^{-2}$ higher than predicted by CB05_GE over most regions except Australia $\left(0.003 \mathrm{mg} \mathrm{m}^{-2}\right.$ lower). MOZART$4 \mathrm{x}$ includes SOA formation from benzene, which can predict higher ASOA formation. In addition, $\mathrm{OH}$ predicted by MOZART-4x is higher than CB05_GE (see Fig. 8a), which can produce more condensable SOA gaseous precursors through oxidations of VOCs. The higher BVOC emissions in MOZART-4x due to different mapping for MEGAN species can also contribute to the higher BSOA formation in MOZART-4x.

Both MOZART-4x and CB05_GE predict POA burdens of $0.36 \mathrm{Tg}$, which is about $0.1 \mathrm{Tg}$ lower than those by Shrivastava et al. (2015), indicating that POA may be too volatile with the current implementation of VBS SOA in CESM/CAM5 and possible lower POA emissions used in this work. MOZART-4x predicts an SOA burden of $1.82 \mathrm{Tg}$, which is slightly higher (by $0.05 \mathrm{Tg}$ ) than that predicted by Shrivastava et al. (2015). This can be attributed to different emissions used in CESM/CAM5 and Shrivastava et al. (2015), as well as differences in the model treatment for SOA formation in both works. For example, nine volatility bins are used in this work to represent the aging and gasparticle partitioning of POA, instead of the five volatility bins used in Shrivastava et al. (2015). In addition, compared to Reaction (3) in Shrivastava et al. (2015), the remaining mass is assumed to be lost to a species with a volatility higher than the volatility values in the VBS structure, instead of being oxidized to form $\mathrm{CO} / \mathrm{CO}_{2}$.

\section{Conclusions}

In this work, MOZART-4x and CB05_GE are coupled with CAM5-NCSU. MOZART-4x uses the lumped species approach to represent organic chemistry, whereas CB05_GE uses the lumped structure approach. MOZART-4x and CB05_GE include different surrogates for SOA precursors, which can result in different SOA predictions. MOZART$4 \mathrm{x}$ includes $\mathrm{HO}_{x}$ recycling associated with improved isoprene chemistry, whereas CB05_GE contains simpler isoprene chemistry, which can result in different $\mathrm{OH}$ and isoprene predictions and, thus, SOA predictions. CB05_GE includes additional oxidation of $\mathrm{SO}_{2}$ by $\mathrm{O}_{3}$ over the surface of dust particles to produce additional $\mathrm{SO}_{4}^{2-}$, which is not included in MOZART-4x. These differences can result in different secondary gas and aerosol predictions.

The comparisons between the two gas-phase mechanisms are conducted in terms of chemical and cloud/radiative predictions. Predictions of major gases and inorganic aerosols predicted by MOZART-4x and CB05_GE are overall similar. Significant differences in some species (e.g., $\mathrm{NO}_{y}$, glyoxal, and SOA) predictions are mainly due to the different reaction pathways treated in the two mechanisms. Large biases exist for surface $\mathrm{SO}_{2}, \mathrm{CO}, \mathrm{NH}_{3}, \mathrm{PM}_{2.5}$ and $\mathrm{PM}_{10}$ predictions against available observations, which is likely due to the uncertainties in the emissions or emission injection heights. Several studies indicate that the uncertainties in regional emissions (e.g., $\mathrm{BC}$ and $\mathrm{SO}_{2}$ ) can be expected to be as large as a factor of 2 or larger (Bond et al., 2007; Smith et al., 2011). Large discrepancies still remain for ma- 
jor species such as $\mathrm{SO}_{2}, \mathrm{NO}_{x}, \mathrm{BC}$, and $\mathrm{CO}$ among different inventories (Granier et al., 2011). Both surface CO mixing ratios and column $\mathrm{CO}$ mass abundances are underpredicted, which is mainly due to underestimations in the $\mathrm{CO}$ emissions from biomass burning and possible uncertainties in the $\mathrm{OH}$ production. The surface $\mathrm{SO}_{2}$ mixing ratio is overpredicted, whereas column $\mathrm{SO}_{2}$ abundance is underpredicted, indicating the uncertainties in the vertical mixing scheme or emission injection heights as reported in East Asia (Zhang et al., 2016a, b), as well as satellite retrievals. For example, Lee et al. (2009) found that there is an overall error in the annual $\mathrm{SO}_{2}$ retrievals of $45-80 \%$ over polluted regions, especially over eastern China. Uncertainties in online dust and sea-salt emissions can also result in inaccurate predictions in $\mathrm{PM}_{2.5}$ and $\mathrm{PM}_{10}$. Both MOZART-4x and CB05_GE overpredict surface $\mathrm{O}_{3}$ over CONUS, Europe, and East Asia, which is due in part to less $\mathrm{O}_{3}$ titration resulting from underpredictions of $\mathrm{NO}_{x}$, the dilution of $\mathrm{NO}_{x}$ emissions resulting from the use of a coarse grid resolution, as well as uncertainties in the $\mathrm{O}_{3}$ dry deposition simulated in the model.

The concentration of OC over CONUS is well predicted by MOZART-4x, with an NMB of $2.1 \%$, whereas it is moderately underpredicted by CB05_GE, with an NMB of $-20.7 \%$. Compared to the observations at the four sites in the US from Lewandowski et al. (2013), SOA is well predicted by MOZART-4x, with an NMB of $-1.9 \%$, whereas it is moderately underpredicted by CB05_GE, with an NMB of $-23.1 \%$, indicating a better capability to predict SOA over these sites by MOZART-4x despite its tendency to overpredict SOA concentrations at sites with low SOA levels such as Bakersfield and Pasadena, CA. However, the concentrations of OC over Europe are largely underpredicted by both MOZART-4x and CB05_GE, with NMBs of -74.2 and $-75.1 \%$, respectively, indicating the uncertainties in the emissions, chemical reactions, as well as SOA formation treatment. The different AOD predictions between CB05_GE and MOZART-4x are mainly due to different predictions in $\mathrm{SOA}, \mathrm{SO}_{4}^{2-}, \mathrm{NH}_{4}^{+}, \mathrm{NO}_{3}^{-}$, and dust concentrations.

The cloud/radiative predictions from the two simulations are also similar, with slightly better domain average performances of CCN5, LWP, and LWCF in CB05_GE. But MOZART-4x predicts a slightly better $\mathrm{CCN}$ profile over Beijing than CB05_GE compared to aircraft measurements. The different gas-phase mechanisms result in different predictions in aerosols and clouds and, therefore, a domain average difference of $0.5 \mathrm{~W} \mathrm{~m}^{-2}$ in simulated SWCF, which can be as large as $13.6 \mathrm{~W} \mathrm{~m}^{-2}$ over subtropical regions.

In summary, MOZART-4x and CB05_GE differ in their approaches to representing VOCs and surrogates for SOA precursors. MOZART-4x includes a more detailed representation of isoprene chemistry compared to CB05_GE. Based on the above comparisons of simulations using both mechanisms and evaluation against available measurements in this study, MOZART-4x with the 1.5 D VBS SOA module in CESM-NCSU generally gives a better agreement with obser- vations for surface concentrations of $\mathrm{O}_{3}$ over Europe, $\mathrm{HNO}_{3}$, $\mathrm{HCHO}$, ISOP over CONUS, SOA, $\mathrm{SO}_{4}^{2-}, \mathrm{NO}_{3}^{-}$, and $\mathrm{NH}_{4}^{+}$ over CONUS and Europe, and column mass abundances of $\mathrm{HCHO}, \mathrm{C}_{2} \mathrm{H}_{2} \mathrm{O}_{2}, \mathrm{SO}_{2}$, and $\mathrm{O}_{3}$, whereas CB05_GE generally gives a better agreement for surface concentrations of $\mathrm{SO}_{2}$, $\mathrm{NH}_{3}, \mathrm{O}_{3}$ over CONUS and East Asia, $\mathrm{HNO}_{3}$ over Europe, $\mathrm{PM}_{2.5}$ and $\mathrm{PM}_{10}$ over Europe, $\mathrm{PM}_{10}$ over East Asia, vertical profiles of $\mathrm{NO}_{y}$, and column mass abundances of $\mathrm{CO}$. Both simulations give predictions of cloud/radiative variables with slightly better domain average performance of CCN5, LWP, and LWCF in CB05_GE.

\section{Code and data availability}

The results in this paper are based on output from simulations performed with the NCAR Community Earth System Model (CESM) version 1.2.2 (https://www2.cesm.ucar.edu/models/ current) with additional model development and modifications by the Air Quality Forecasting Laboratory, North Carolina State University, Raleigh, NC, USA. The added codes have been provided to NCAR for potential future release and to NCAR for community use. Upon request, we can provide the inputs, the namelist file, a brief instruction, and sample output for a 1-day test case.

\section{The Supplement related to this article is available online at doi:10.5194/gmd-8-3999-2015-supplement.}

Acknowledgements. This work is sponsored by the US National Science Foundation EaSM program AGS1049200 and the NCAR Advanced Study Program. MODIS data and CERES data are provided by NASA via http://ladsweb.nascom.nasa.gov/data/search.html and http://ceres.larc.nasa.gov/order_data.php, respectively. CDNC data are provided by Ralf Bennartz. Other surface network data were downloaded from their respective web sites. ARCPAC and CalNex data are from NOAA, STRAT08 data are from NCAR, ARCTAS data are from NASA, CCN_China are from Zhang et al. (2011), and SOA data of Lewandowski et al. (2013) are provided by Tadeusz Kleindienst, US EPA. We would like to acknowledge high-performance computing support from Yellowstone (ark:/85065/d7wd3xhc) provided by NCAR's Computational and Information Systems Laboratory, sponsored by the US National Science Foundation. The National Center for Atmospheric Research is operated by the University Corporation for Atmospheric Research with funding from the National Science Foundation.

Edited by: J. Williams 


\section{References}

Aghedo, A. M., Bowman, K. W., Worden, H. M., Kulawik, S. S., Shindell, D. T., Lamarque, J.-F., Faluvegi, G., Parrington, M., Jones, D. B. A., and Rast, S.: The vertical distribution of ozone instantaneous radiative forcing from satellite and chemistry climate models, J. Geophys. Res., 116, D01305, doi:10.1029/2010JD014243, 2011.

Barahona, D., West, R. E. L., Stier, P., Romakkaniemi, S., Kokkola, H., and Nenes, A.: Comprehensively accounting for the effect of giant $\mathrm{CCN}$ in cloud activation parameterizations, Atmos. Chem. Phys., 10, 2467-2473, doi:10.5194/acp-10-2467-2010, 2010.

Bennartz, R.: Global assessment of marine boundary layer cloud droplet number concentration from satellite, J. Geophys. Res., 112, D02201, doi:10.1029/2006JD007547, 2007.

Boersma, K. F., Eskes, H. J., and Brinksma, E. J.: Error analysis for tropospheric $\mathrm{NO}_{2}$ retrieval from space, J. Geophys. Res., 109, D04311, doi:10.1029/2003JD003962, 2004.

Bond, T. C., Bhardwaj, E., Dong, R., Jogani, R., Jung, S., Roden, C., Streets, D. G., and Trautmann, N. M.: Historical emissions of black and organic carbon aerosol from energy-related combustion, 1850-2000, Global Biogeochem. Cy., 21, GB2018, doi:10.1029/2006GB002840, 2007.

Brock, C. A., Cozic, J., Bahreini, R., Froyd, K. D., Middlebrook, A. M., McComiskey, A., Brioude, J., Cooper, O. R., Stohl, A., Aikin, K. C., de Gouw, J. A., Fahey, D. W., Ferrare, R. A., Gao, R.-S., Gore, W., Holloway, J. S., Hübler, G., Jefferson, A., Lack, D. A., Lance, S., Moore, R. H., Murphy, D. M., Nenes, A., Novelli, P. C., Nowak, J. B., Ogren, J. A., Peischl, J., Pierce, R. B., Pilewskie, P., Quinn, P. K., Ryerson, T. B., Schmidt, K. S., Schwarz, J. P., Sodemann, H., Spackman, J. R., Stark, H., Thomson, D. S., Thornberry, T., Veres, P., Watts, L. A., Warneke, C., and Wollny, A. G.: Characteristics, sources, and transport of aerosols measured in spring 2008 during the aerosol, radiation, and cloud processes affecting Arctic Climate (ARCPAC) Project, Atmos. Chem. Phys., 11, 2423-2453, doi:10.5194/acp-11-24232011, 2011.

Cappa, C. D. and Jimenez, J. L.: Quantitative estimates of the volatility of ambient organic aerosol, Atmos. Chem. Phys., 10, 5409-5424, doi:10.5194/acp-10-5409-2010, 2010.

Chan, A. W. H., Kautzman, K. E., Chhabra, P. S., Surratt, J. D., Chan, M. N., Crounse, J. D., Kürten, A., Wennberg, P. O., Flagan, R. C., and Seinfeld, J. H.: Secondary organic aerosol formation from photooxidation of naphthalene and alkylnaphthalenes: implications for oxidation of intermediate volatility organic compounds (IVOCs), Atmos. Chem. Phys., 9, 3049-3060, doi:10.5194/acp-9-3049-2009, 2009.

Couvidat, F., Kim, Y., Sartelet, K., Seigneur, C., Marchand, N., and Sciare, J.: Modeling secondary organic aerosol in an urban area: application to Paris, France, Atmos. Chem. Phys., 13, 983-996, doi:10.5194/acp-13-983-2013, 2013.

Emmons, L. K., Walters, S., Hess, P. G., Lamarque, J.-F., Pfister, G. G., Fillmore, D., Granier, C., Guenther, A., Kinnison, D., Laepple, T., Orlando, J., Tie, X., Tyndall, G., Wiedinmyer, C., Baughcum, S. L., and Kloster, S.: Description and evaluation of the Model for Ozone and Related chemical Tracers, version 4 (MOZART-4), Geosci. Model Dev., 3, 43-67, doi:10.5194/gmd3-43-2010, 2010.

Fountoukis, C. and Nenes, A.: Continued Development of a Cloud Droplet Formation Parameterization for Global Climate Mod- els, J. Geophys. Res., 110, D11212, doi:10.1029/2004JD005591, 2005.

Fountoukis, C. and Nenes, A.: ISORROPIA II: a computationally efficient thermodynamic equilibrium model for $\mathrm{K}^{+}$ $\mathrm{Ca}^{2+}-\mathrm{Mg}^{2+}-\mathrm{NH}_{4}^{+}-\mathrm{Na}^{+}-\mathrm{SO}_{4}^{2-}-\mathrm{NO}_{3}^{-}-\mathrm{Cl}^{-}-\mathrm{H}_{2} \mathrm{O}$ aerosols, Atmos. Chem. Phys., 7, 4639-4659, doi:10.5194/acp-7-4639-2007, 2007.

Gantt, B., He, J., Zhang, X., Zhang, Y., and Nenes, A.: Incorporation of advanced aerosol activation treatments into CESM/CAM5: model evaluation and impacts on aerosol indirect effects, Atmos. Chem. Phys., 14, 7485-7497, doi:10.5194/acp-14-74852014, 2014.

Gery, M. W., Whitten, G. Z., Killus, J. P., and Dodge, M. C.: A photochemical kinetics mechanism for urban and regional scale computer modeling, J. Geophys. Res., 94, 12925-12956, doi:10.1029/JD094iD10p12925, 1989.

Glotfelty, T., He, J., and Zhang, Y.: Updated organic aerosol treatments in CESM/CAM5: development and initial application, in preparation, 2015.

Granier, C., Bessagnet, B., Bond, T., D’Angiola, A., Denier van der Gon, H., Frost, G. J., Heil, A., Kaiser, J. W., Kinne, S., Klimont, Z., Kloster, S., Lamarque, J.-F., Liousse, C., Masui, T., Meleux, F., Mieville, A., Ohara, T., Raut, J.-C., Riahi, K., Schultz, M. G., Smith, S. J., Thompson, A., van Aardenne, J., van der Werf, G. R., and van Vuuren, D. P.: Evolution of anthropogenic and biomass burning emissions of air pollutants at global and regional scales during the 1980-2010 period, Climatic Change, 109, 163-190, doi:10.1007/s10584-011-0154-1, 2011.

Guenther, A. B., Jiang, X., Heald, C. L., Sakulyanontvittaya, T., Duhl, T., Emmons, L. K., and Wang, X.: The Model of Emissions of Gases and Aerosols from Nature version 2.1 (MEGAN2.1): an extended and updated framework for modeling biogenic emissions, Geosci. Model Dev., 5, 1471-1492, doi:10.5194/gmd-51471-2012, 2012.

He, J. and Zhang, Y.: Improvement and further development in CESM/CAM5: gas-phase chemistry and inorganic aerosol treatments, Atmos. Chem. Phys., 14, 9171-9200, doi:10.5194/acp14-9171-2014, 2014.

He, J., Zhang, Y., Glotfelty, T., He, R., Bennartz, R., Rausch, J., and Sartelet, K.: Decadal simulation and comprehensive evaluation of CESM/CAM5.1 and advanced chemistry, aerosol microphysics, and aerosol-cloud interactions, J. Adv. Model. Earth Syst., 7, 110-141, doi:10.1002/2014MS000360, 2015.

Hodzic, A., Jimenez, J. L., Madronich, S., Canagaratna, M. R., DeCarlo, P. F., Kleinman, L., and Fast, J.: Modeling organic aerosols in a megacity: potential contribution of semi-volatile and intermediate volatility primary organic compounds to secondary organic aerosol formation, Atmos. Chem. Phys., 10, 5491-5514, doi:10.5194/acp-10-5491-2010, 2010.

IPCC: Climate Change 2013: The Physical Science Basis. Contribution of Working Group I to the Fifth Assessment Report of the Intergovernmental Panel on Climate Change, edited by: Stocker, T. F., Qin, D., Plattner, G.-K., Tignor, M., Allen, S. K., Boschung, J., Nauels, A., Xia, Y., Bex, V., and Midgley, P. M., Cambridge University Press, Cambridge, UK and New York, NY, USA, 1535 pp., doi:10.1017/CBO9781107415324, 2013.

Jacob, D. J. and Winner, D. A.: Effect of climate change on air quality, Atmos. Environ., 43, 51-63, 2009. 
Jacob, D. J., Crawford, J. H., Maring, H., Clarke, A. D., Dibb, J. E., Emmons, L. K., Ferrare, R. A., Hostetler, C. A., Russell, P. B., Singh, H. B., Thompson, A. M., Shaw, G. E., McCauley, E., Pederson, J. R., and Fisher, J. A.: The Arctic Research of the Composition of the Troposphere from Aircraft and Satellites (ARCTAS) mission: design, execution, and first results, Atmos. Chem. Phys., 10, 5191-5212, doi:10.5194/acp-10-5191-2010, 2010.

Jathar, S. H., Farina, S. C., Robinson, A. L., and Adams, P. J.: The influence of semi-volatile and reactive primary emissions on the abundance and properties of global organic aerosol, Atmos. Chem. Phys., 11, 7727-7746, doi:10.5194/acp-11-77272011, 2011.

Jimenez, J. L., Canagaratna, M. R., Donahue, N. M., Prevot, A. S. H., Zhang, Q., Kroll, J. H., DeCarlo, P. F., Allan, J. D., Coe, H., Ng, N. L., Aiken, A. C., Docherty, K. S., Ulbrich, I. M., Grieshop, A. P., Robinson, A. L., Duplissy, J., Smith, J. D., Wilson, K. R., Lanz, V. A., Hueglin, C., Sunn, Y. L., Tian, J., Laaksonen, A., Raatikainen, T., Rautiainen, J., Vaattovaara, P., Ehn, M., Kulmala, M., Tomlinson, J. M., Collins, D. R., Cubison, M. J., Dunlea, E., J., Huffman, J. A., Onaasch, T. B., Alfarra, M. R., Williams, P. I., Bower, K., Kondo, Y., Schneider, J., Drewnick, F., Borrmann, S., Weimer, S., Demerjian, K., Salcedo, D., Cottrell, L., Griffin, R., Takami, A., Miyoshi, T., Hatakeyama, S., Shimono, A., Sun, J. Y., Zhang, Y. M., Dzepina, K., Kimmel, J. R., Sueper, D., Jayne, J. T., Herndon, S. C., Trimborn, A. M., Williams, L. R., Wood, E. C., Middlebrook, A. M., Kolb, C. E., Baltensperger, U., and Worsnop, D. R.: Evolution of organic aerosols in the atmosphere, Science, 326, 1525-1529, doi:10.1126/science.1180353, 2009.

Karamchandani, P., Zhang, Y., Chen, S.-Y., and Balmori-Bronson, R.: Development of an extended chemical mechanism for globalthrough-urban applications, Atmospheric Pollution Research, 3, 1-24, 2012.

Kay, J. E., Hillman, B. R., Klein, S. A., Zhang, Y., Medeiros, B., Pincus, R., Gettelman, A., Eaton, B., Boyle, J., Marchand, R., and Ackerman, T. P.: Exposing global cloud biases in the Community Atmosphere Model (CAM) using satellite observations and their corresponding instrument simulators, J. Climate, 25, 5190-5207, doi:10.1175/JCLI-D-11-00469.1, 2012.

Kim Y., Sartelet, K., and Seigneur C.: Comparison of two gas-phase chemical kinetic mechanisms of ozone formation over Europe, J. Atmos. Chem., 62, 89-119, doi:10.1007/s10874-009-9142-5, 2009.

Kim, Y., Sartelet, K., and Seigneur, C.: Formation of secondary aerosols over Europe: comparison of two gas-phase chemical mechanisms, Atmos. Chem. Phys., 11, 583-598, doi:10.5194/acp-11-583-2011, 2011a.

Kim, Y., Couvidat, F., Sartelet, K., and Seigneur, C.: Comparison of Different Gas-Phase Mechanisms and Aerosol Modules for Simulating Particulate Matter Formation, J. Air Waste Manage., 61, 1218-1226, availble at: http://www.tandfonline.com/doi/pdf/ 10.1080/10473289.2011.603999 (last access: July 2015), $2011 \mathrm{~b}$.

Kinnison, D. E., Brasseur, G. P., Walters, S., Garcia, R. R., Marsh, D. A., Sassi, F., Boville, B. A., Harvey, L., Randall, C., Emmons, L., Lamarque, J.-F., Hess, P., Orlando, J., Tyndall, G., Tie, X. X., Randel, W., Pan, L., Gettelman, A., Granier, C., Diehl, T., Niemeier, U., and Simmons, A. J.: Sensitivity of chemical tracers to meteorological parameters in the MOZART-
3 chemical transport model, J. Geophys. Res., 112, D20302, doi:10.1029/2006JD007879, 2007.

Knote, C., Tuccella, P., Curci, G., Emmons, L., Orlando, J. J., Madronich, S., Baró, R., Jiménez-Guerrero, P., Luecken, D., Hogrefe, C., Forkel, R., Werhahn, J., Hirtl, M., Pérez, J. L., San José, R., Giordano, L., Brunner, D., Khairunnisa, Y., and Zhang, Y.: Influence of the choice of gas-phase mechanism on predictions of key gaseous pollutants during the AQMEII phase-2 intercomparison, Atmos. Environ., 115, 553568, doi:10.1016/j.atmosenv.2014.11.066, 2014a.

Knote, C., Hodzic, A., Jimenez, J. L., Volkamer, R., Orlando, J. J., Baidar, S., Brioude, J., Fast, J., Gentner, D. R., Goldstein, A. H., Hayes, P. L., Knighton, W. B., Oetjen, H., Setyan, A., Stark, H., Thalman, R., Tyndall, G., Washenfelder, R., Waxman, E., and Zhang, Q.: Simulation of semi-explicit mechanisms of SOA formation from glyoxal in aerosol in a 3-D model, Atmos. Chem. Phys., 14, 6213-6239, doi:10.5194/acp-14-6213-2014, 2014 b.

Kumar, P., Sokolik, I. N., and Nenes, A.: Parameterization of cloud droplet formation for global and regional models: including adsorption activation from insoluble CCN, Atmos. Chem. Phys., 9, 2517-2532, doi:10.5194/acp-9-2517-2009, 2009.

Lamarque, J.-F. and Solomon, S.: Impact of Changes in Climate and Halocarbons on Recent Lower Stratosphere Ozone and Temperature Trends, J. Climate, 23, 2599-2611, 2010.

Lamarque, J.-F., Kinnison, D. E., Hess, P. G., and Vitt, F.: Simulated lower stratospheric trends between 1970 and 2005: identifying the role of climate and composition changes, J. Geophys. Res., 113, D12301, doi:10.1029/2007JD009277, 2008.

Lamarque, J.-F., Bond, T. C., Eyring, V., Granier, C., Heil, A., Klimont, Z., Lee, D., Liousse, C., Mieville, A., Owen, B., Schultz, M. G., Shindell, D., Smith, S. J., Stehfest, E., Van Aardenne, J., Cooper, O. R., Kainuma, M., Mahowald, N., McConnell, J. R., Naik, V., Riahi, K., and van Vuuren, D. P.: Historical (1850-2000) gridded anthropogenic and biomass burning emissions of reactive gases and aerosols: methodology and application, Atmos. Chem. Phys., 10, 7017-7039, doi:10.5194/acp10-7017-2010, 2010.

Lamarque, J.-F., McConnell, J. R., Shindell, D. T., Orlando, J. J., and Tyndall, G. S.: Understanding the drivers for the 20th century change of hydrogen peroxide in Antarctic ice-cores, Geophys. Res. Lett., 38, L04810, doi:10.1029/2010GL045992, 2011a.

Lamarque, J.-F., Kyle, G. P., Meinshausen, M., Riahi, K., Smith, S. J., van Vuuren, D. P., Conley, A., and Vitt, F.: Global and regional evolution of short-lived radiatively-active gases and aerosols in the Representative Concentration Pathways, Climatic Change, 109, 191-212, $2011 \mathrm{~b}$.

Lamarque, J.-F., Emmons, L. K., Hess, P. G., Kinnison, D. E., Tilmes, S., Vitt, F., Heald, C. L., Holland, E. A., Lauritzen, P. H., Neu, J., Orlando, J. J., Rasch, P. J., and Tyndall, G. K.: CAM-chem: description and evaluation of interactive atmospheric chemistry in the Community Earth System Model, Geosci. Model Dev., 5, 369-411, doi:10.5194/gmd-5-369-2012, 2012.

Lamarque, J.-F., Shindell, D. T., Josse, B., Young, P. J., Cionni, I., Eyring, V., Bergmann, D., Cameron-Smith, P., Collins, W. J., Doherty, R., Dalsoren, S., Faluvegi, G., Folberth, G., Ghan, S. J., Horowitz, L. W., Lee, Y. H., MacKenzie, I. A., Nagashima, T., Naik, V., Plummer, D., Righi, M., Rumbold, S. T., Schulz, M., Skeie, R. B., Stevenson, D. S., Strode, S., Sudo, K., Szopa, S., 
Voulgarakis, A., and Zeng, G.: The Atmospheric Chemistry and Climate Model Intercomparison Project (ACCMIP): overview and description of models, simulations and climate diagnostics, Geosci. Model Dev., 6, 179-206, doi:10.5194/gmd-6-179-2013, 2013.

Lee, C., Martin, R. V., Donkelaar, A. van, O’Byrne, G., Krotkov, N., Richter, A., Huey, L. G., and Holloway, J. S.: Retrieval of vertical columns of sulfur dioxide from SCIAMACHY and OMI: Air mass factor algorithm development, validation, and error analysis, J. Geophys. Res., 114, D22303, doi:10.1029/2009JD012123, 2009.

Levy, R. C., Mattoo, S., Munchak, L. A., Remer, L. A., Sayer, A. M., Patadia, F., and Hsu, N. C.: The Collection 6 MODIS aerosol products over land and ocean, Atmos. Meas. Tech., 6, 29893034, doi:10.5194/amt-6-2989-2013, 2013.

Lewandowski, M., Piletic, I. R., Kleindienst, T. E., Offenberg, J. H., Beaver, M. R., Jaoui, M., Docherty, K. S., and Edney, E. O.: Secondary organic aerosol characterization at field sites across the United States during the spring-summer period, Int. J. Environ. An. Ch., 93, 1084-1103, 2013.

Liu, X., Zhang, Y., Cheng, S.-H., Xing, J., Zhang, Q., Streets, D. G., Jang, C., Wang, W.-X., and Hao, J.-M.: Understanding of regional air pollution over China using CMAQ, partI: performance evaluation and seasonal variation, Atmos. Environ., 44, 24152426, doi:10.1016/j.atmosenv.2010.03.035, 2010.

Liu, X., Easter, R. C., Ghan, S. J., Zaveri, R., Rasch, P., Shi, X., Lamarque, J.-F., Gettelman, A., Morrison, H., Vitt, F., Conley, A., Park, S., Neale, R., Hannay, C., Ekman, A. M. L., Hess, P., Mahowald, N., Collins, W., Iacono, M. J., Bretherton, C. S., Flanner, M. G., and Mitchell, D.: Toward a minimal representation of aerosols in climate models: description and evaluation in the Community Atmosphere Model CAM5, Geosci. Model Dev., 5, 709-739, doi:10.5194/gmd-5-709-2012, 2012.

Luecken, D. J., Phillips, S., Sarwar, G., and Jang, C.: Effects of using the CB05 vs. SAPRC99 vs. CB4 chemical mechanism on model predictions: Ozone and gas-phase photochemical precursor concentrations, Atmos. Environ., 42, 5805-5820, doi:10.1016/j.atmosenv.2007.08.056, 2008.

Ma, P.-L., Rasch, P. J., Wang, H., Zhang, K., Easter, R. C., Tilmes, S., Fast, J. D., Liu, X., Yoon, J.-H., and Lamarque, J.-F.: The role of circulation features on black carbon transport into the Arctic in the Community Atmosphere Model version 5 (CAM5), J. Geophys. Res.-Atmos., 118, 4657-4669, doi:10.1002/jgrd.50411, 2013.

Martensson, E. M., Nilsson, E. D., deLeeuw, G., Cohen, L. H., and Hansson, H. C.: Laboratory simulations and parameterization of the primary marine aerosol production, J. Geophys. Res., 108, 4297, doi:10.1029/2002JD002263, 2003.

Martin, M. V., Heald, C. L., and Arnold, S. R.: Coupling dry deposition to vegetation phenology in the Community Earth System Model: Implications for the simulation of surface $\mathrm{O}_{3}$, Geophys. Res. Lett., 41, 2988-2996, doi:10.1002/2014GL059651, 2014.

May, A. A., Presto, A. A., Hennigan, C. J., Nguyen, N. T., Gordon, T. D., and Robinson, A. I.: Gas-particle partitioning of primary organic aerosol emissions: (1), gasoline vehicle exhaust, Atmos. Environ., 77, 128-139, doi:10.1016/j.atmosenv.2013.04.060, 2013a.

May, A. A., Levin, E. J. T., Hennigan, C. J., Riipinen, I., Lee, T., Collett Jr., J. L., Jimenez, J. L., Kreidenweis, S. M., and Robin- son, A. L.: Gas-particle partitioning of primary organic aerosol emissions: 3. Biomass burning, J. Geophys. Res.-Atmos., 118, 11327-11338, doi:10.1002/jgrd.50828, 2013b.

Meinshausen, M., Smith, S. J., Calvin, K., Daniel, J. S., Kainuma, M. L. T., Lamarque, J.-F., Matsumoto, K., Montzka, S., Raper, S., Riahi, K., Thomson, A., Velders, G. J. M., and van Vuuren, D. P.: The RCP Greenhouse gas concentrations and their extensions from 1765 to 2300, Climatic Change, 109, 213-241, 2011.

Merikanto, J., Napari, I., Vehkamaki, H., Anttila, T., and Kulmala, M.: New parameterization of sulfuric acid-ammonia-water ternary nucleation rates at tropospheric conditions, J. Geophys. Res., 112, D15207, doi:10.1029/2006JD007977, 2007.

Naik, V., Voulgarakis, A., Fiore, A. M., Horowitz, L. W., Lamarque, J.-F., Lin, M., Prather, M. J., Young, P. J., Bergmann, D., Cameron-Smith, P. J., Cionni, I., Collins, W. J., Dalsøren, S. B., Doherty, R., Eyring, V., Faluvegi, G., Folberth, G. A., Josse, B., Lee, Y. H., MacKenzie, I. A., Nagashima, T., van Noije, T. P. C., Plummer, D. A., Righi, M., Rumbold, S. T., Skeie, R., Shindell, D. T., Stevenson, D. S., Strode, S., Sudo, K., Szopa, S., and Zeng, G.: Preindustrial to present-day changes in tropospheric hydroxyl radical and methane lifetime from the Atmospheric Chemistry and Climate Model Intercomparison Project (ACCMIP), Atmos. Chem. Phys., 13, 5277-5298, doi:10.5194/acp-13-5277-2013, 2013.

Pan, L. L., Bowman, K. P., Atlas, E. L., Wofsy, S. C., Zhang, F., Bresch, J. F., Ridley, B. A., Pittman, J. V., Homeyer, C. R., Romashkin, P., and Cooper, W. A.: The stratosphere-troposphere analyses of regional transport 2008 (START08) experiment, B. Am. Meteorol. Soc., 91, 327-342, 2010.

Price, C. and Rind, D.: A simple lightning parameterization for calculating global lightning distributions, J. Geophys. Res., 97, 9919-9933, doi:10.1029/92JD00719, 1992.

Price, C., Penner, J., and Prather, M.: $\mathrm{NO}_{x}$ from lightning 1, Global distribution based on lightning physics, J. Geophys. Res., 102, 5929-5941, 1997.

Reff, A., Bhave, P. V., Simon, H., Pace, T. G., Pouliot, G. A., Mobley, J. D., and Houyoux, M.: Emissions inventory of $\mathrm{PM}_{2.5}$ trace elements across the United States, Environ. Sci. Technol., 43, 5790-5796, doi:10.1021/es802930x, 2009.

Reutter, P., Su, H., Trentmann, J., Simmel, M., Rose, D., Gunthe, S. S., Wernli, H., Andreae, M. O., and Pöschl, U.: Aerosol- and updraft-limited regimes of cloud droplet formation: influence of particle number, size and hygroscopicity on the activation of cloud condensation nuclei (CCN), Atmos. Chem. Phys., 9, 70677080, doi:10.5194/acp-9-7067-2009, 2009.

Robinson, A. L., Donahue, N. M., Shrivastava, M. K., Weitkamp, E. A., Sage, A. M., Grieshop, A. P., Lane, T. E., Pierce, J. R., and Pandis, S. N.: Rethinking organic aerosols: Semivolatile emissions and photochemical aging, Science, 315, 1259-1262, doi:10.1126/science.1133061, 2007.

Ryerson, T. B., Andrews, A. E., Angevine, W. M., Bates, T. S., Brock, C. A., Cairns, B., Cohen, R. C., Cooper, O. R., de Gouw, J. A., Fehsenfeld, F. C., Ferrare, R. A., Fischer, M. L., Flagan, R. C., Goldstein, A. H., Hair, J. W., Hardesty, R. M., Hostetler, C. A., Jimenez, J. L., Langford, A. O., McCauley, E., McKeen, S. A., Molina, L. T., Nenes, A., Oltmans, S. J., Parrish, D. D., Pederson, J. R., Pierce, R. B., Prather, K., Quinn, P. K., Seinfeld, J. H., Senff, C. J., Sorooshian, A., Stutz, J., Surratt, J. D., Trainer, M., Volkamer, R., Williams, E. J., and Wofsy, S. C.: The 
2010 California Research at the Nexus of Air Quality and Climate Change (CalNex) field study, J. Geophys. Res., 118, 58305866, doi:10.1002/jgrd.50331, 2013.

Sarwar, G., Luecken, D., Yarwood, G., Whitten, G., and Carter, W. P. L.: Impact of an updated carbon bond mechanism on predictions from the Community Multiscale Air Quality Model, J. Appl. Meteorol. Clim., 47, 3-14, doi:10.1175/2007JAMC1393.1, 2008.

Seethala, C. and Horvath, Á.: Global assessment of AMSR$\mathrm{E}$ and MODIS cloud liquid water path retrievals in warm oceanic clouds, J. Geophys. Res., 115, D13202, doi:10.1029/2009JD012662, 2010.

Shrivastava, M., Zelenyuk, A., Imre, D., Easter, R., Beranek, J., Zaveri, R. A., and Fast, J.: Implications of low volatility SOA and gas-phase fragmentation reactions on SOA loadings and their spatial and temporal evolution in the atmosphere, J. Geophys. Res., 118, 3328-3342, doi:10.1002/jgrd.50160, 2013.

Shrivastava, M., Easter, R., Liu, X., Zelenyuk, A., Singh, B., Zhang, K., Ma, P.-L., Chand, D., Ghan, S., Jimenez, J. L., Zhang, Q., Fast, J., Rasch, P., and Tiitta, P.: Global transformation and fate of SOA: Implications of low volatility SOA and gas-phase fragmentation reactions, J. Geophys. Res.-Atmos., 120, 4169-4195, doi:10.1002/2014JD022563, 2015.

Shrivastava, M. K., Lane, T. E., Donahue, N. M., Pandis, S. N., and Robinson, A. L.: Effects of gas particle partitioning and aging of primary emissions on urban and regional organic aerosol concentrations, J. Geophys. Res., 113, D18301, doi:10.1029/2007JD009735, 2008.

Smith, S. J., van Aardenne, J., Klimont, Z., Andres, R. J., Volke, A., and Delgado Arias, S.: Anthropogenic sulfur dioxide emissions: 1850-2005, Atmos. Chem. Phys., 11, 1101-1116, doi:10.5194/acp-11-1101-2011, 2011.

Stainer, C. O., Donahue, N., and Pandis, S. N.: Parameterization of secondary organic aerosol mass fractions from smog chamber data, Atmos. Environ., 42, 2276-2299, doi:10.1016/j.atmosenv.2007.12.042, 2008.

Taylor, K. E: Summarizing multiple aspects of model performance in a single diagram, J. Geophys. Res., 106, 7183-7192, 2001.

Tilmes, S., Lamarque, J.-F., Emmons, L. K., Kinnison, D. E., Ma, P.-L., Liu, X., Ghan, S., Bardeen, C., Arnold, S., Deeter, M., Vitt, F., Ryerson, T., Elkins, J. W., Moore, F., Spackman, J. R., and Val Martin, M.: Description and evaluation of tropospheric chemistry and aerosols in the Community Earth System Model (CESM1.2), Geosci. Model Dev., 8, 1395-1426, doi:10.5194/gmd-8-13952015, 2015.

Tsimpidi, A. P., Karydis, V. A., Zavala, M., Lei, W., Molina, L., Ulbrich, I. M., Jimenez, J. L., and Pandis, S. N.: Evaluation of the volatility basis-set approach for the simulation of organic aerosol formation in the Mexico City metropolitan area, Atmos. Chem. Phys., 10, 525-546, doi:10.5194/acp-10-525-2010, 2010.

Vehkamaki, H., Kulmala, M., Napari, I., Lehtinen, K. E. J., Timmreck., C., Noppel, M., and Laaksonen, A.: an improved parameterization for sulfuric acid-water nucleation rates for tropospheric and stratospheric conditions, J. Geophys. Res.-Atmos., 107, 4622, doi:10.1029/2002JD002184, 2002.

Wang, H., Easter, R. C., Rasch, P. J., Wang, M., Liu, X., Ghan, S. J., Qian, Y., Yoon, J.-H., Ma, P.-L., and Vinoj, V.: Sensitivity of remote aerosol distributions to representation of cloud-aerosol interactions in a global climate model, Geosci. Model Dev., 6, 765-782, doi:10.5194/gmd-6-765-2013, 2013.

Wang, K., Yahya, K., Zhang, Y., Wu, S.-Y., and Grell, G.: Implementation and initial application of a new chemistry-aerosol option in WRF/Chem for simulation of secondary organic aerosols and aerosol indirect effects, Atmos. Environ, 115, 716-732, doi:10.1016/j.atmosenv.2014.12.007, 2014.

Wang, M. and Penner, J. E.: Aerosol indirect forcing in a global model with particle nucleation, Atmos. Chem. Phys., 9, 239-260, doi:10.5194/acp-9-239-2009, 2009.

Washenfelder, R., Young, C., Brown, S., Angevine, W., Atlas, E., Blake, D., Bon, D., Cubison, M., De Gouw, J., Dusanter, S., Flynn, J., Gilman, J. B., Graus, M., Griffith, S., Grossberg, N., Hayes, P. L., Jimenez, J., Kuster, W., Lefer, B. L., Pollack, I., Ryerson, T., Stark, H., Stevens, P. S., and Trainer, M.: The glyoxal budget and its contribution to organic aerosol for Los Angeles, California, during CalNex 2010, J. Geophys. Res., 116, D00V02, doi:10.1029/2011JD016314, 2011.

Yarwood, G., Rao, S., Yocke, M., and Whitten, G. Z.: Updates to the carbon bond mechanism: CB05, Report to the US Environmental Protection Agency, Novato, CA, USA, RT-04-00675, 2005.

Yarwood, G., Kemball-Cook, S., Johnson, J., Wilson, G., Dornblaser, B., and Estes, M.: Evaluating $\mathrm{NO}_{x}$ Emission Inventories for Air Quality Modeling Using Satellite, Model and SEARCH $\mathrm{NO}_{2}$ Data, oral presentation at 11th Annual CMAS conference, 16 October 2012, Chapel Hill, NC, USA, 1-21, 2012.

Young, P. J., Archibald, A. T., Bowman, K. W., Lamarque, J.-F., Naik, V., Stevenson, D. S., Tilmes, S., Voulgarakis, A., Wild, O., Bergmann, D., Cameron-Smith, P., Cionni, I., Collins, W. J., Dalsøren, S. B., Doherty, R. M., Eyring, V., Faluvegi, G., Horowitz, L. W., Josse, B., Lee, Y. H., MacKenzie, I. A., Nagashima, T., Plummer, D. A., Righi, M., Rumbold, S. T., Skeie, R. B., Shindell, D. T., Strode, S. A., Sudo, K., Szopa, S., and Zeng, G.: Preindustrial to end 21st century projections of tropospheric ozone from the Atmospheric Chemistry and Climate Model Intercomparison Project (ACCMIP), Atmos. Chem. Phys., 13, 2063 2090, doi:10.5194/acp-13-2063-2013, 2013.

Yu, F.: Ion-mediated nucleation in the atmosphere: Key controlling parameters, implications, and look-up table, J. Geophys. Res., 115, D03206, doi:10.1029/2009JD012630, 2010.

Yu, S., Mathur, R., Sarwar, G., Kang, D., Tong, D., Pouliot, G., and Pleim, J.: Eta-CMAQ air quality forecasts for $\mathrm{O}_{3}$ and related species using three different photochemical mechanisms (CB4, CB05, SAPRC-99): comparisons with measurements during the 2004 ICARTT study, Atmos. Chem. Phys., 10, 30013025, doi:10.5194/acp-10-3001-2010, 2010.

Yu, S.-C., Dennis, R., Roselle, S., Nenes, A., Walker, J., Eder, B., Schere, K., Swall, J., and Robarge, W.: An assessment of the ability of 3-D air quality models with current thermodynamic equilibrium models to predict aerosol $\mathrm{NO}_{3}^{-}$, J. Geophys. Res., 110, D07S13, doi:10.1029/2004JD004718, 2005.

Yu, S.-C., Eder, B., Dennis, R., Chu, S.-H., and Schwartz, S.: New unbiased symmetric metrics for evaluation of air quality models, Atmos. Sci. Lett., 7, 26-34, 2006.

Zender, C. S., Bian, H., and Newman, D.: The mineral Dust Entrainment And Deposition (DEAD) model: Description and 1990s dust climatology, J. Geophys. Res., 108, 4416, doi:10.1029/2002JD002775, 2003. 
Zhang, Q., Jimenez, J. L., Canagaratna, M. R., Allan, J. D., Coe, H., Ulbrich, I., Alfarra, M. R., Takami, A., Middlebrook, A. M., Sun, Y. L., Dzepina, K., Dunlea, E., Docherty, K., DeCarlo, P. F., Salcedo, D., Onasch, T., Jayne, J. T., Miyoshi, T., Shimono, A., Hatakeyama, S., Takegawa, N., Kondo, Y., Schneider, J., Drewnick, F., Borrmann, S., Weimer, S., Demerjian, K., Williams, P., Bower, K., Bahreini, R., Cottrell, L., Griffin, R. J., Rautiainen, J., Sun, J. Y., Zhang, Y. M., and Worsnop, D. R.: Ubiquity and dominance of oxygenated species in organic aerosols in anthropogenically-influenced Northern Hemisphere midlatitudes, Geophys. Res. Lett., 34, L13801, doi:10.1029/2007GL029979, 2007.

Zhang, Q., Quan, J., Tie, X., Huang, M., and Ma, X.: Impacts of aerosol particles on cloud formation: Aircraft measurements in China, Atmos. Environ., 45, 665-672, 2011.

Zhang, Y., Pun, B., Vijayaraghavan, K., Wu, S.-Y., Seigneur, C., Pandis, S., Jacobson, M., Nenes A., and Seinfeld, J. H.: Development and Application of the Model of Aerosol Dynamics, Reaction, Ionization and Dissolution (MADRID), J. Geophys. Res., 109, D01202, doi:10.1029/2003JD003501, 2004.

Zhang, Y., Liu, P., Pun, B., and Seigneur, C.: A comprehensive performance evaluation of MM5-CMAQ for summer 1999 Southern Oxidants Study episode, Part I. Evaluation protocols, databases, and meteorological predictions, Atmos. Environ., 40, 48254838, 2006 .
Zhang, Y., Karamchandani, P., Glotfelty, T., Street, D. G., Grell, G., Nenes, A., Yu, F., and Bennartz, R.: Development and initial application of the global-through-urban weather research and forecasting model with chemistry (GU-WRF/Chem), J. Geophys. Res., 117, D20206, doi:10.1029/2012JD017966, 2012a.

Zhang, Y., Chen, Y., Sarwar, G., and Schere, K.: Impacts of gasphase mechanisms on weather research forecasting model with chemistry (WRF/Chem) predictions: Mechanism implementation and comparative evaluation, J. Geophys. Res., 117, D01301, doi:10.1029/2011JD015775, 2012b.

Zhang, Y., Zhang, X., Wang, L.-T., Zhang, Q., Duan, F.-K., and He, K.-B.: Application of WRF/Chem over East Asia: Part I. Model Evaluation and Intercomparison with MM5/CMAQ, Atmos. Environ., 124, 285-300, doi:10.1016/j.atmosenv.2015.07.022, 2016a.

Zhang, Y., Zhang, X., Wang, K., Zhang, Q., Duan, F.-K., and He, K.-B.: Application of WRF/Chem over East Asia: Part II. Model Improvement and Sensitivity Simulations, Atmospheric Environment, 124, 301-320, doi:10.1016/j.atmosenv.2015.07.023, $2016 b$. 